\title{
EL MECENAZGO DE DON JUAN DE SANCLEMENTE. UN CORDOBÉS ARZOBISPO DE SANTIAGO
}

\author{
RAMÓN YZQUIERDO PERRÍN \\ Universidade da Coruña
}

\section{Resumen}

Don Juan de Sanclemente nació en Córdoba. Se formó en Alcalá, Sigüenza y Valladolid, de cuya Universidad fue catedrático. Pasó luego a ser canónigo de Badajoz, donde conoció a Felipe II, quien lo promovió al episcopado. Fue obispo de Ourense, (15791587), y arzobispo de Santiago (1587-1602).

Implantó en sus diócesis las disposiciones del concilio de Trento, de donde derivó parte significativa de su mecenazgo: promover la construcción de nuevos coros y otras actuaciones. Los ataques de Drake y la flota inglesa a Galicia, el hambre y pestes que siguieron probaron su fortaleza. La formación de niños y jovenes le llevó a fundar colegios gratuitos y, tras su muerte, el magníficio Colegio de Sanclemente de Pasantes en Santiago.

\section{Palabras clave}

Córdoba, Valladolid, Badajoz, Felipe II, concilio de Trento, Ourense, Santiago de Compostela, Drake, jesuitas, colegio de Huérfanas, colegio de San Clemente, coros capitulares.

\section{THE PATRONAGE OF DON JUAN OF SANCLEMENTE. A CORDOVAN ARCHBISHOP OF SANTIAGO.}

\begin{abstract}
Don Juan of Sanclemente was born in Cordoba. He was formed in Alcalá, Sigüenza and Valladolid, whose University was professor. He later became a canon of Badajoz, where he met Felipe II, who promoted him to the episcopate. He was bishop of Ourense, (1579-1587), and archbishop of Santiago (1587-1602).

He implanted in their dioceses the provisions of the Council of Trent, from which derived a significant part of their patronage: promoting the construction of new choirs and other interventions. Drake's attacks and the English fleet to Galicia, hunger and plagues that followed proved his strength. The education of children and young people led him to found free schools, and after his death, the magnificent Sanclemente of Pasantes School in Santiago.
\end{abstract}

\section{Keywords}

Cordoba, Valladolid, Badajoz, Felipe II, Council of Trent, Ourense, Santiago de Compostela, Drake, Jesuits, orphans school, San Clemente school, Chapter choirs 


\section{Introducción.}

El episcopologio de Santiago de Compostela cuenta con ocho arzobispos andaluces entre 1400 y 1948. La primera fecha corresponde a la toma de posesión del sevillano don Lope de Mendoza ${ }^{1}$, cuyo pontificado se prolongó hasta 1445 y es hasta la actualidad el de mayor duración; la segunda, al fallecimiento del onubense don Tomás Muniz Pablos ${ }^{2}$. Casi en el medio de ese largo período de quinientos cincuenta años desarrolló su episcopado compostelano don Juan de Sanclemente y Torquemada ${ }^{3}$, quien accedio a la sede de Santiago en 1587 y falleció en 1602.

\section{Apunte biográfico}

La biografía de don Juan de Sanclemente es bien conocida porque se dispone de una encomiástica vida escrita por su familiar y secretario Pedro Sanz del Castillot quien hace honor a su condición y ensalza las virtudes del prelado hasta extremos insospechados, al tiempo que omite aquellos otros aspectos más polémicos (Fig. 1).

Nació en Córdoba el 19 de agosto de 1534 en el seno de una familia acomodada, emparentada con san Juan de Ávila, de quien se dice que profetizó, al verlo de niño, que sería: "operario grande en la Iglesia". Se trasladó a estudiar a Alcalá, viviendo en casa de otro insigne pariente: Ambrosio de Morales, y en 1553 obtuvo el grado de maestro con diecinueve años. Por entonces consiguió una beca para proseguir su formación en el Colegio de San Antonio de Sigüenza, donde se doctoró y recibió ordenes mayores. En diciembre de 1563 obtuvo una beca de teología en el Colegio de Santa Cruz de Valladolid, donde fue Regente de Artes y catedrático de Filosofía en la Universidad de esta ciudad. Por oposición consiguió en 1569 la plaza de canónigo magistral de la catedral de Badajoz. Su estancia aquí y la fama que había adquirido le permitió conocer al rey Felipe II, clave en su "cursus honorum", quien se había detenido en ella cuando se dirigía a Portugal a causa de un ataque de gota.

Al vacar la sede de Ourense en 1578 por traslado a la de Salamanca del obispo Fernando Tricio de Arenzana, Felipe II propuso el 7 de julio del mismo año a Sanclemente para regirla ${ }^{5}$. El nombramiento se produjo el 5 de septiembre, le causó gran confusión y tras

Fig. 1. Portada de: "Vida de don Juan de Sanclemente", por Pedro Sanz De Castillo. Santiago, 1709.(Foto Archivo Yzquierdo).

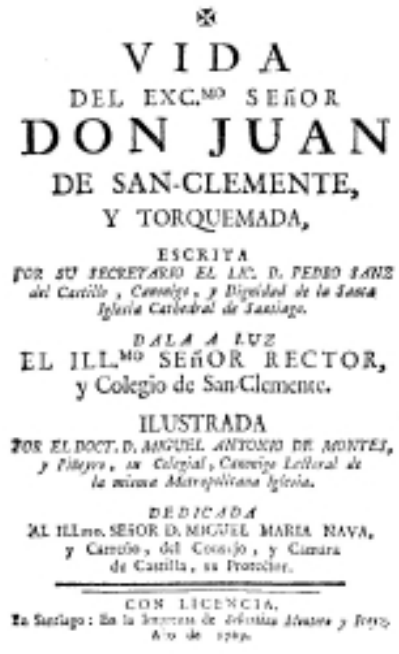

\footnotetext{
${ }^{1}$ López Ferreiro, 1904: 7 y ss.. Yzquierdo Perrín, 2006-2007: 117-172.

2 Cebrián Franco, 1997: 332-340. En este libro puede espigarse la nómina de los arzobispos de origen andaluz, así como una semblanza de sus personas y actuaciones más destacadas.

${ }^{3}$ López Ferreiro, 1906a: 301-364. González García-Paz, 1993: 21 y ss. Cebrián Franco, 1997: 196-203. Andrés Ordax, 2015: 79-81.

${ }^{4}$ Sanz del Castillo, 1769. De esta rara publicación se hacía eco: Villa-amil y Castro, 1875: 137-138, ficha 260.

5 Pazos, 1946b: 342-344. Flórez, 2005: 172-173.
} 


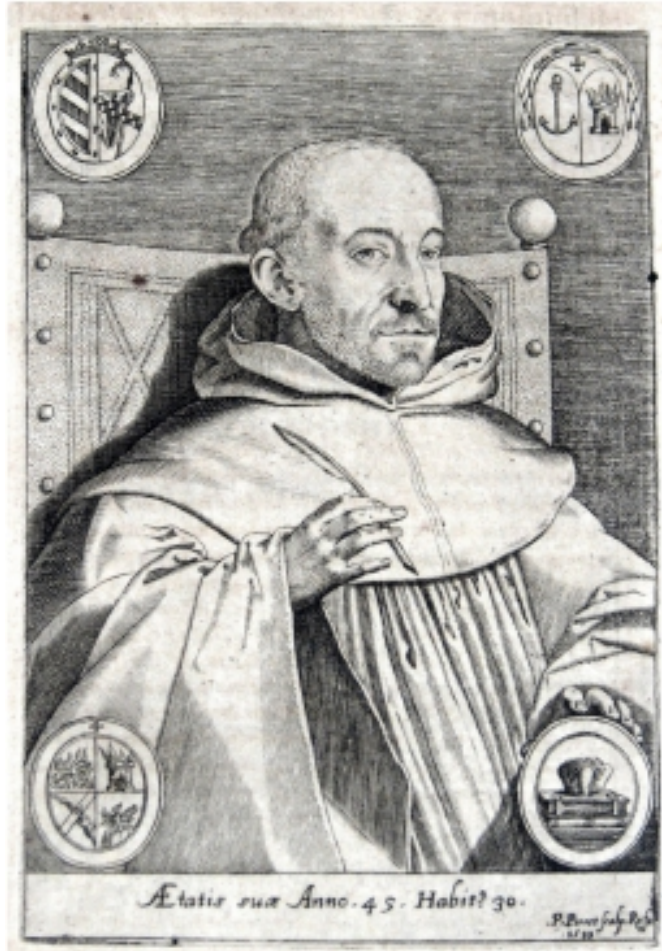

Fig. 2. Retrato de don Juan de Sanclemente en 1579 (Universidad de Murcia. Biblioteca.Colección Histórica).En: http://fcd2.inf.um.es:808 $0 /$ jspui/handle/9/110

larga deliberación, oraciones y el consejo de Fray Luís de Granada, Ambrosio de Morales y el arzobispo compostelano Francisco Blanco, lo aceptó. Este prelado lo ordenó obispo en la catedral de Santiago el 25 de enero de 1579 en una ceremonia a la que también asistieron los prelados de Tui y Lugo. Sanclemente ocuparía la sede compostelana ocho años después al proponerlo, también, Felipe II (Fig. 2).

Tanto en Ourense como más adelante en Santiago don Juan de Sanclemente destacó por su celo pastoral, como evidencian sus visitas diocesanas y la celebración de sínodos, de los que en los ocho años que fue obispo de Ourense, por ejemplo, celebró cinco ${ }^{6}$, se preocupó de que los oficios litúrgicos se celebraran con la debida solemnidad, en particular en el coro, para lo que mejoró las condiciones económicas de los músicos y ministros que a él asistían. Decisiones que generaron ciertas fricciones entre el obispo y el cabildo de la catedral.

La renuncia por enfermedad a la sede compostelana del arzobispo Alonso Velázquez en los inicios de 1587 y su muerte, pocos días después, facilitó a Felipe II proponer a Juan de Sanclemente para sucederle, decisión que le comunicó el monarca y le suscitó los mismos escrúpulos y necesidad de consultar a diversos personajes sobre la conveniencia de aceptarla o rechazarla ${ }^{7}$ que cuando lo nombraron obispo de Ourense. Fue preconizado arzobispo de Santiago el 27 de julio del mismo año, fecha en la que cesó como obispo. La demora en la llegada de las bulas con su nombramiento propició que su sucesor en Ourense tomara posesión de la sede antes de que aquéllas llegaran, por lo que las esperó en Tui y dedicó ese período a informarse del estado de su nueva diócesis, de la que se posesionó el 12 de octubre de 1587, aunque el palio propio de su dignidad, traído de Roma por el obispo de Lugo, no lo recibió hasta comienzos de diciembre por lo que su entrada en Santiago la hizo el día 11 de dicho mes.

\footnotetext{
${ }^{6}$ Fernández Alonso, 1897: 443. Duro Peña, 1996: 44 y 147.

${ }^{7}$ González Dávila, 1645: 112-113. Pazos, 1946a: 100-117.
} 
Intervenciones patrimoniales de don juan de sanclemente en ourense.

De los años que don Juan de Sanclemente rigió la diócesis de Ourense: 1579-1587, lo más destacado en lo religioso son los cinco sínodos que celebró en tan corto episcopado que, como precisa Muñoz de la Cueba", tenían por objeto: "la reforma del Clero", es decir, implantar las disposiciones del Concilio de Trento en la diócesis. Un poco después afirma este autor que: "Hizo en su Iglesia singulares Beneficios, assi en obras costosas, útiles y necessarias, como en unir algunas Raciones a la fábrica, para la manutención de la Capilla de música y Ministros del Coro". En el fondo, pues, todas sus intervenciones se encaminaban a reformar al clero y a que los ritos corales tuvieran la brillantez y grandeza que Trento les otorgaba, que era lo que pretendían las mejoras que introdujo.

La catedral de Ourense contaba desde finales del siglo XIII o comienzos del XIV con un: "coro gótico con muros de piedra y acaso también asientos de piedra" que, posiblemente, tenía como referencia el pétreo compostelano y Fernández Alonso estimaba que debió de hacerse en el último tercio del $\mathrm{XV}^{9}$. En el centro del testero había una puerta y los primeros asientos, los más cercanos al crucero de la catedral, correspondían al rey y al obispo. Es decir, al margen de que fuera pobre e incómodo su mayor defecto para Sanclemente era su inadecuación a las directrices de Trento que sancionaban la práctica, en vigor desde el siglo XV, de que los obispos no los elegían los cabildos, sino que los nombraba Roma, aunque algunos monarcas, como el hispano, tenían el privilegio de proponer candidatos a la Santa Sede. Respecto a la preeminencia del prelado en su diócesis el concilio ${ }^{10}$ proclamaba que: "en todas partes se ha de tributar a los obispos aquel honor que es debido a su dignidad; y ocupen el asiento y el lugar que ellos mismos eligieren en el coro, en las procesiones y en otros actos públicos, así como tendrán la máxima autoridad en la dirección de cuanto haya de hacerse".

Cuando Sanclemente llevaba en Ourense año y medio, el 10 de junio de 1580, se contrató ante notario la ejecución de un nuevo coro para la catedral que se haría conforme a la traza dada por Juan de Angés el Mozo y Diego de Solís, previamente examinada por Esteban Jordán a petición del cabildo. La obra se prolongó hasta 1598 y al año siguiente Juan de Angés pide que se nombren tasadores ${ }^{11}$. Aunque es probable que los primeros movimientos para sustituir el viejo coro medieval se iniciaran durante el episcopado de su predecesor en la sede, Tricio de Arenzana, que contribuyó a su ejecución con dos donativos: uno de 500 ducados y, cuando estuvo terminado, envió desde Salamanca otro de 900, lo cierto es que la firma del contrato para su renovación se sustanció con Juan de Sanclemente al frente de la diócesis y, a pesar de que no se concluyó durante su pontificado, mandó 400 ducados para contribuir a su hechura. La primera vez que se entró en el nuevo coro fue el 24 de marzo de 1589. En el centro del testero se alzaba la silla del prelado, diferenciada de las restantes (Fig. 3). En los muros perimetrales que lo separaban de las naves colaterales se mantuvieron las piezas góticas que al suprimir el coro se reutilizaron como frontal del altar mayor actual así como bajo varios sarcófagos situados a lo largo de los muros catedralicios.

La ambiciosa obra del coro, una vez terminada, hizo necesario acometer algunas intervenciones complementarias en las que, de nuevo, está presente la mediación de Sanclemente, a pesar de ser entonces arzobispo de Santiago, tales como las rejas del coro, capilla mayor y púlpitos ${ }^{12}$. En la reunión del cabildo de Ourense de 8 de abril de 1589 se dio cuenta de lo tratado con el obispo, don Pedro González de Acevedo, para dotar a la catedral

\footnotetext{
${ }^{8}$ Muñoz de la Cueba, 1727: 279-280.

${ }^{9}$ Fernández Alonso, 1913: 297-306. Duro Peña, 1996: 28. Goy Diz, 1998: 590-592. Yzquierdo Perrín, 2011: 831-832.

${ }^{10}$ Citado por Navascués Palacio, 1998: 29.

11 Sánchez Arteaga, 1916: 91-95. De esta obra existe nueva edición preparada por Saco Cid, J.L. y una biografía del autor de González García, M.A. Ourense, 2005. Vila Jato, 1983: 59-65. González García, 1993 : 96-100. García Iglesias, 1998: 533-534.

12 Sánchez Arteaga, 1916: 98-101. Chamoso Lamas, 1957: 307-310. Gallego de Miguel, 1963: 140-149. Vila Jato, 1983: 44-45. González García, 1993:110-111. Goy Diz, 1998: 592-593.
} 


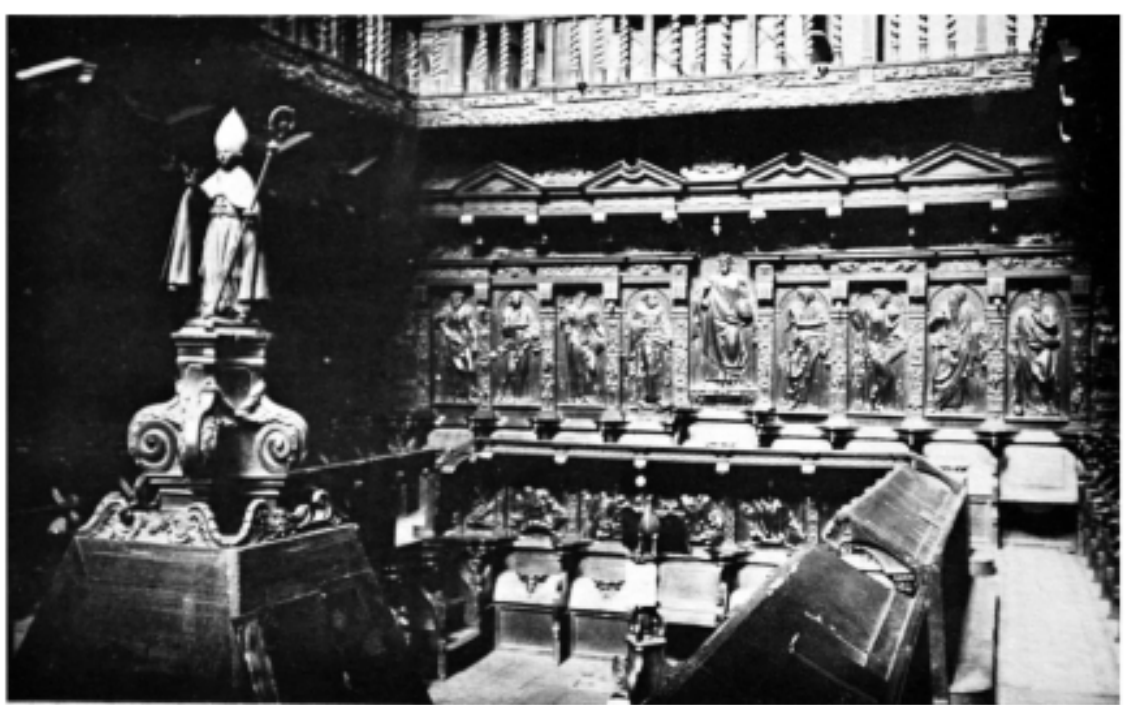

Fig. 3. Testero del coro de la catedral de Ourense en su emplazamiento original. Foto anterior a 1937 (Foto Archivo Yzquierdo).

de unas rejas en el coro y capilla mayor, así como de púlpitos, conforme a la oferta enviada desde Santiago por Juan Bautista Celma quien se comprometía a hacerlo por 3100 ducados $^{13}$. Aceptan la propuesta y resuelven agradecer a Sanclemente su mediación, al tiempo que le piden su conformidad, otorgada el 3 de julio del mismo año, día en que se firmó el nuevo contrato, con el compromiso de Celma de tener todo acabado para la: "Pascua de flores de 1591".

Como la obra no avanzaba con la celeridad requerida y ante la inquietud del cabildo orensano sale fiador del artista el propio Sanclemente: "Digo yo Don Juan de Sanclemente Arçobispo de Santiago que por cuanto Bautista Celma, maestro de obras de esta Nuestra Iglesia de Santiago, de pintura y escultura, ha tomado la obra de las rexas de la Catedral de Orense en tres mil y ducientos y cinquenta ducados y es hombre abonado y que siempre ha dado buena quenta y cumplido con las obras que se le han encomendado; en caso que él muriese o faltase o viniese alguna quiebra por su parte, me obligo a hazer cumplir la dicha obra según el dicho Bautista Celma estava obligado a cumplillo y a ello me obligo con mis bienes spirituales y temporales y lo firmo en Santiago a quince de Março de mill y quinientos y noventa y un años". El 7 de julio de 1595 el cabildo de Ourense se dirige de nuevo al prelado y le recuerda su aval ante la demora de Celma en el cumplimiento del contrato. A pesar de todo el cabildo tuvo que esperar hasta enero de 1597 para liquidar el encargo ${ }^{14}$.

Las magníficas rejas de Celma permanecen en la catedral, aunque no cierran ya el coro ni la capilla mayor (Fig. 4), sino los lados norte y sur del tramo central del crucero. Una vez colocadas en sus emplazamientos iniciales se doraron: la del coro, a costa del arzobispo Sanclemente, quien el 11 de enero de 1596 hizo llegar al cabildo un escrito y un donativo de 600 ducados; la de la capilla mayor y púlpitos, se doraron a costa del obispo Pedro González de Acevedo que de Ourense había pasado a regir la diócesis de Plasencia. Por su parte los púlpitos, deudores de los que Celma hizo en bronce para la catedral compostelana, aunque sin su riqueza escultórica e iconográfica, siguen desempeñando su función. $\mathrm{Al}$ igual que en Santiago los tornavoces son barrocos.

El coro de la catedral de Ourense no corrió mejor suerte que tantos otros y en 1937 se retiró, durante el largo episcopado de don Florencio Cerviño González. Los muros que lo

\footnotetext{
13 A pesar de este compromiso pronto, como se verá enseguida, el importe ascendía a 3250 ducados.
}

14 Pérez Costanti, 1930: 127. 
cerraban, se demolieron y las piezas góticas se reutilizaron. Por su parte la sillería se repartió y reubicó en diferentes estancias de la catedral: la alta, en los laterales de la capilla del Santo Cristo; la baja, en la capilla mayor, como si fuera el basamento de su espléndido retablo; otras piezas fueron a parar al museo catedralicio y vestuario de canónigos, por ejemplo. Finalmente, los órganos laterales, considerados los dos órganos viejos del coro, se regalaron al santuario de los Milagros y a santa Eufemia del Norte. La justificación del desmembramiento ${ }^{15}$ es la habitual: "con la demolición del coro, que interrumpía la magnífica perspectiva de la naves, se restituyó el edificio a su fábrica primitiva".

Además de estas importantes intervenciones don Juan de Sanclemente también disponía sobre asuntos de menos importancia. En 1583 mandó al cabildo que retirara: "una ymagen de Nuestra Señora de piedra que está yndecentemente en la nave de Nuestra Señora sobre un entierro" "16. La identificación de esta imagen con la Virgen de Belen, que preside un altar barroco en el muro sur del Pórtico del Paraíso, originó cierta polémica sobre su procedencia, origen $^{17}$, clasificación y cronología. Hoy se considera obra gótica, basada en recetas de Reims, y se fecha a mediados del siglo XIII. Desconocemos si es la que mandó retirar Sanclemente, si lo fuera podría deberse a lo escrito por su predecesor, don Fernando Tricio de Arenzana, en 1568 tras la visita girada a la catedral. La maltrecha capilla de san Marcos tenía pintado en su retablo un san Cristóbal, estaba detrás del coro y: "en el... estaba una imagen de Nuestra Señora con su hijo bendito". Cabe preguntarse si la decisión de Sanclemente guardaba relación con la obra del coro. Quizá es casual que frente a la imagen, en el muro norte del Pórtico del Paraíso, está pintado un enorme san Cristobal.

\section{El arzobispo Sanclemente y el corsario Drake}

Desde 1585 las desavenencias entre España y Gran Bretaña tienen en el Atlántico su principal teatro de operaciones y su punto álgido se produce con el imprevisto desastre de la Armada Invencible en 1588. Poco antes, el 11 de diciembre de 1587, don Juan de Sanclemente entró en Santiago de Compostela como su arzobispo, cargo que desempeñó durante más de catorce años. De inmediato realiza visita pastoral a la catedral e iglesias de la ciudad, pero cuando se disponía a continuarla por el resto de su diócesis un inesperado y grave acontecimiento le obligó a modificar sus planes. El corsario inglés Drake ataca las costas de Galicia, desembarca en diversos puntos en los que roba, saquea e incendia propiedades e iglesias y concentra su arremetida en el puerto de A Coruña, pues en él se habían refugiado parte de los barcos de la Armada Invencible que lograron retornar a la península. Sus embestidas y movimientos, así como el riesgo que sus acciones suponían para las reliquias custodiadas en la catedral compostelana obligaron a Sanclemente a tomar drásticas e insólitas decisiones.

El 4 de mayo de 1589 Drake se presenta ante A Coruña con una flota de ciento veinte barcos en los que viajaba un ejército de más de diecisiete mil soldados. El marqués de Cerralbo, capitan general de Galicia, solicita ayuda para hacer frente a tan grave amenaza y planifica la defensa del puerto y de la ciudad. Ante tal resistencia Drake desembarca en Santa María de Oza para atacar por tierra a A Coruña y hacerse con ella. En el asalto surgió la heroína María Pita que se convirtió en la mas intrépida defensora frente al invasor ${ }^{18}$. A finales de junio la flota de Drake buscó refugio en la ría de Vigo y, tras desembarcar en Teis, cometieron las habituales tropelías: saqueos e incendios, en particular de bienes eclesiásticos.

15 Duro Peña, 1996: 30. Bande, 2005: 179. Sobre los órganos del coro: Sánchez Arteaga, 1916: 96-98. Duro Peña, 1996: 265 y ss.. En la p. 296 dice que el órgano que se había hecho entre 1922 y 1924 por la Casa Eleizegaray, al desmontarse el coro, se trasladó a la tribuna existente sobre el Pórtico del Paraíso.

${ }^{16}$ Citado por Conde Cid, 2015: 203 y nota 381 de la misma página.

17 Sánchez Arteaga, 1916: 108-109. Nota 1. Domínguez Fontela, 1935: 64-65. Moralejo Álvarez, 1975: 25. Chao Castro, 2005: 118-120.

18 Rodríguez Solís, 1898. Saavedra Vázquez, 1998: 115 y ss., en particular pp. 123-133. González GarcíaPaz, 1993: 260-265, (Doc. VII. Relación del cerco de La Coruña). 
Las destrucciones e incendio de iglesias en los alrededores de A Coruña y el avance por tierra de los ingleses llevaron a don Juan de Sanclemente a reunirse con el cabildo catedralicio el 9 de mayo para prevenir la destrucción de los tesoros de la iglesia compostelana, considerada por Drake el: "principal emporio de la superstición papal”. Decidieron que los más importantes libros y documentos del archivo catedralicio, así como los vasos sagrados y ornamentos se trasladaran, acompañados por un miembro del cabildo y varios capellanes, a un recóndito lugar del centro de Galicia, a la torre de Camba ${ }^{19}$, -Rodeiro. Pontevedra-. Es posible que en la misma reunión acordaran que las numerosas reliquias con que contaba la catedral se llevaran a la de Ourense pues, llegado el caso, funcionaría como una fortaleza pero, sorprendentemente, el acta nada dice de ellas, aunque ya estaban en Ourense el día 12 acompañadas por el canónigo doctor Osma, que se quedó allí hasta que retornaron a Santiago.

Ante el imparable avance de los ingleses y las alarmantes noticias que llegan a Santiago el 12 de mayo el arzobispo fortifica la ciudad, cierra la muralla y organiza y dota de armamento a dos compañías de soldados, mandadas por Ginés Rodríguez y los condes de Lemos y de Altamira. Al mismo tiempo hace salir a las mujeres y niños para que se refugien en tierras alejadas del itinerario hacia Portugal, pues era a donde pretendían llegar los invasores. Tan pronto pasó el peligro Sanclemente socorrió a la veintena de iglesias incendiadas y destruidas en los alrededores de A Coruña con dos mil ducados, enviándoles además cálices y ornamentos, piezas destinadas al culto que adquiría en Granada y que cada año de su episcopado distribuía entre las parroquias más necesitadas.

Curiosamente ningún documento menciona las reliquias más importantes de cuantas poseía Compostela: las del apóstol Santiago y sus discípulos Teodoro y Atanasio, y tampoco alude a ellas el acta de recepción del cabildo de Ourense, en la que se dice que se habían enviado "la mayor parte" de las de la catedral. En la Historia del Apóstol Santiago, de Bugarín ${ }^{20}$, se relata que cuando el arzobispo pretendió sacar de su sitio los restos mortales del Apóstol se produjo un resplandor que le hizo declinar su propósito al tiempo que decía: "Dejémos al Santo Apóstol, que él se defenderá y nos defenderá". Lo cierto es que el prelado en carta fechada el 18 de mayo de 1589 dirigida a Felipe II le pide que envíe tropas para proteger la ciudad y para que: "este Santo Cuerpo del Apóstol por nuestros pecados no sea profanado de estos bárbaros hereges". Las reliquias, pues, permanecieron en la catedral compostelana, aunque en paradero desconocido hasta la noche del 29 de enero de 1879 en la que fueron descubiertas por López Ferreiro en el curso de las excavaciones arqueológicas que con tal fin llevaba a cabo en ciertos puntos del subsuelo de la basílica ${ }^{21}$.

Pasado el peligro de la invasión el prelado comisionó a dos miembros del cabildo y cuatro capellanes, el 6 de junio, para que fueran a Ourense y retornaran con las reliquias que allí habían llevado. Pero los ataques de Drake y de su flota seguían inquietando al arzobispo, quien se afana en reparar y mejorar la defensa de Compostela ${ }^{22}$, entregando 500 ducados para contribuir a los gastos de reparación el 26 de enero de 1590. En julio de 1596, ante la posibilidad de un nuevo ataque a las costas por parte de la flota inglesa, el rey le pide que tenga preparadas fuerzas defensivas por si fueran necesarias y tanto el prelado como el ayuntamiento evalúan la situación, al tiempo que piensan las tropas que podrían reunir y las medidas más urgentes que debían de tomar con respecto a las maltrechas murallas, algunas de cuyas torres incluso habían sido aforadas en la primera mitad del mismo siglo XVI a particulares para diferentes usos. Las gestiones para repararlas, reuniones y acuerdos se suceden en los últimos años de la centuria sin que se adopten medidas definitivas por su

\footnotetext{
${ }^{19}$ López Ferreiro, 1906a: 307-311. Sanz del Castillo, 1769: 31-33. Bartolini, 1885: 102-106.

${ }^{20}$ Citada por López Ferreiro, 1906a: 311-314.

${ }^{21}$ Bartolini, 1885: 107 y ss.. López Ferreiro, 1891: 24-35; 1906a: 313-314. Guerra Campos, 1985: 105-116. Yzquierdo Perrín, 2004: 22-26.

${ }^{22}$ Rodríguez González, 1969: 395-412. Ortega Romero, 1988: 225-239.
} 


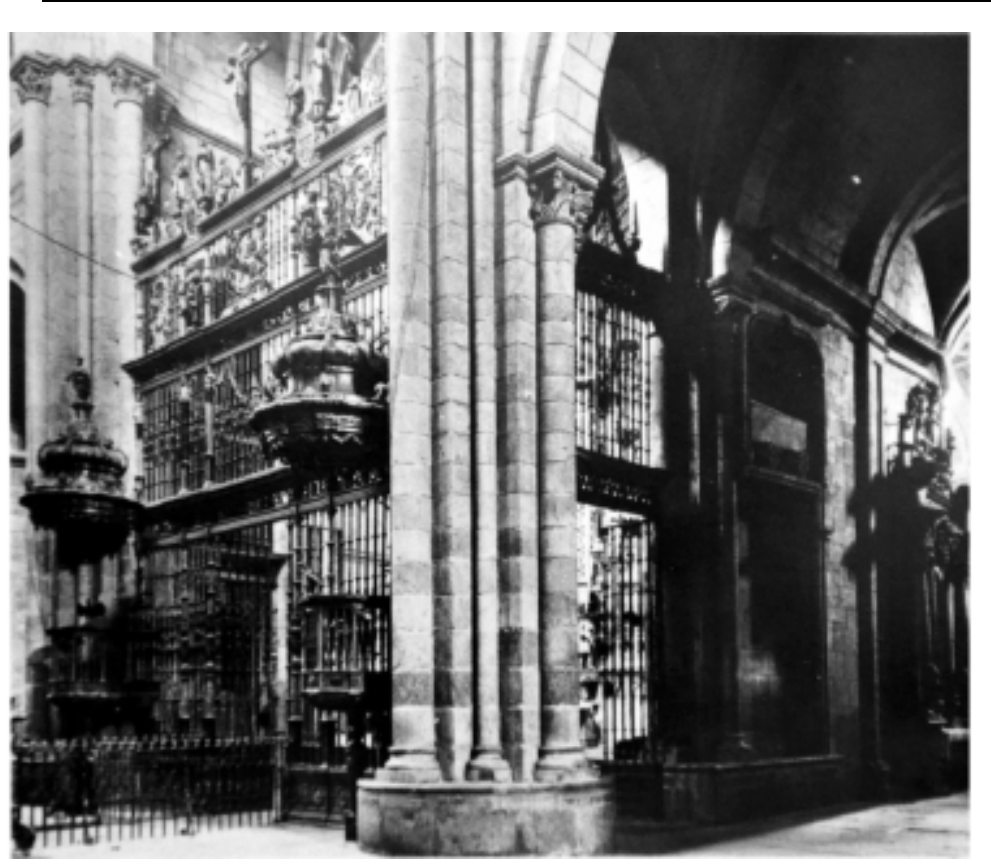

Fig. 4. Catedral de Ourense. Reja de la Capilla mayor y púlpitos. Foto anterior a 1937 (Foto Archivo Yzquierdo).

elevado coste y la falta de medios para llevar a cabo los repasos y reconstrucciones necesarias. Esta penuria también la evidencian las repetidas solicitudes de dinero por parte de Felipe II para los gastos originados por las guerras que entonces mantenía, peticiones que obligaron al cabildo a solicitar prestamos, vender objetos de oro y plata, ornatos y brocados así como tablas y pinturas del palacio arzobispal para ayudar al monarca en sus empresas.

Probablemente las intervenciones en la muralla compostelana en los últimos años del siglo XVI y primeros del XVII fueron más efectivas de lo que dicen los documentos anteriores pues en 1607 Jerónimo del $\mathrm{Hoyo}^{23}$ escribió que: "Esta ciudad está muy bien cercada con buena muralla, la qual está edificada por todas partes sobre peña; tiene muchos torreones y muy espesos, cada uno con su plaça de armas y todo ello con sus almenas. Tiene ocho puertas".

Las periódicas amenazas de la flota inglesa a las costas gallegas, en especial a las de A Coruña, generaron una situación de temor, incertidumbre y ruina que desencadenó una severa hambruna a la que siguió una mortífera peste que diezmó la población. Sanclemente era consciente de tales dificultades por lo que en 1597, junto con el cabildo, trató de paliarlas mediante limosnas y la compra de trigo para repartirlo gratuitamente entre los necesitados. A pesar de sus esfuerzos el hambre y la peste, según Sanz del Castillo ${ }^{24}$, provocaron la muerte en Santiago de unas seis mil personas, algunas residentes en el propio palacio arzobispal. Para atender a los enfermos y moribundos llamó a los Hermanos de San Juan de Dios, quienes organizaron un hospital próximo a la capilla de la Angustia ${ }^{25}$, donde también disponían de un camposanto.

\section{Actuaciones episcopales del arzobispo sanclemente.}

Además de atender a tan graves y urgentes problemas humanos también se ocupó don Juan de Sanclemente de la visita pastoral a la catedral y demás iglesias de su diócesis con el permanente objetivo de que se implantaran y cumplieran puntualmente las disposiciones emanadas del Concilio de Trento, preocupación que le llevó a procurar el buen estado de las iglesias, aunque tuvieran escasos recursos, y a intentar no sólo la adecuada formación del clero, sino también de todos los fieles, independientemente de su grado de instrucción.

\footnotetext{
${ }^{23}$ Hoyo, 1607: 43.

24 Sanz del Castillo, 1769: 45. López Ferreiro, 1906a: 322-327.

${ }^{25}$ López Ferreiro, 1906a: 314-327. Sanz del Castillo, 1769: 44-47. Yzquierdo Perrín, 1997: 62-72.
} 
Fig. 5. Por menor del Claustro del dibujo de Vega y Verdugo, 1656-1657 tomado de la fachada occdidental de la catedral de Ourense. (Foto Archivo Yzquierdo).

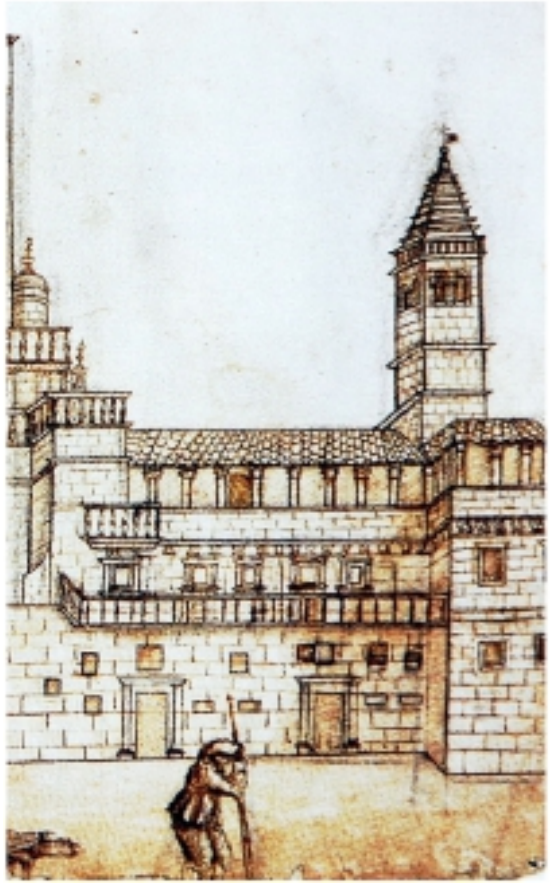

Era consciente del muy elevado analfabetismo que padecía la población de su diócesis y, para paliarlo en lo espiritual, pretendió que la mayoría de las parroquias tuvieran sus muros pintados con diferentes escenas religiosas para que sus imágenes sirvieran de verdaderos libros ilustrados y aleccionadores para los feligreses. Su biógrafo Sanz del Castillo ${ }^{26}$ escribió: "Holgábase infinito ver pintadas las Iglesias, particularmente las Capillas Mayores, que de muchos años lo suelen estar en Galicia con el Cielo y el Infierno, y mandaba renobar estas Pinturas, y decía que: "ellas eran los Libros de los rústicos y ignorantes". Cuestión más árdua e incierta resulta intentar precisar qué pinturas ${ }^{27}$ de las conservadas corresponden no sólo a la época sino también al interés y objetivos del prelado.

Quizá el colofón a estas preocupaciones pastorales lo ejemplifica la reimpresión en 1601, -tan solo un año antes de su muerte-, de las Constitucionales Sinodales elaboradas en el sínodo celebrado por su predecesor, el arzobispo don Francisco Blanco el 5 de junio de 1576, que se encontraban agotadas, como dice el licenciado Landeras ${ }^{28}$, provisor y vicario general del arzobispado quien, en la justificación que precede al texto, manifiesta que los ejemplares de las constituciones sinodales: "son acabadas, y nada ay, y por muchas personas Eclesiásticas de esta Diócesis nos ha sido pedido, atento que ay falta dellas, y no hallarse, mandasemos dar licencia para imprimirlas de nuevo".

\section{Intervenciones patrimoniales en Santiago de Compostela.}

Edificios de la panda oeste del claustro de la catedral.

Durante el episcopado de don Juan de Sanclemente en Santiago proseguían las obras de construcción de los edificios levantados entorno al claustro de la catedral. En los años finales del siglo XVI y primeros del XVII se trabajaba en las dependencias asomadas a la actual plaza del Obradoiro, correspondientes a la sala capitular y biblioteca (Fig. 5), cuya terminación se produjo a comienzos de 1590 y quizá entonces también se acabaron otros

${ }^{26}$ Sanz del Castillo, 1769: 33.

27 García Iglesias, 1986; 1989.

28 Constituciones Synodales del Arzobispado de Santiago hechas por el Illustrisimo y Reverendisimo Señor Don Francisco Blanco... y mandadas imprimir de nuevo por Su Señoría Don Juan de Sant Clemente... en 16 de Mayo de 1601 años. (1601), Santiago. S.p. 
espacios de este flanco. La puerta que da paso a ellas desde la crujía claustral ostenta en su amplio dintel el escudo del arzobispo Sanclemente, aunque la logia columnada del último cuerpo $^{29}$ no se remató hasta fecha cercana a 1614. Sin embargo la intervención del arzobispo en estas obras debió de ser escasa o testimonial ya que estaba ocupado en la reforma del coro, arduo trabajo en el que tenía experiencia de cómo proceder con el cabildo desde su etapa orensana.

\section{Renovación del coro de la catedral.}

A mediados del siglo XVI se colocaron nuevas rejas en el coro capitular que pudieron afectar al inicio de la sillería medieval, construída y labrada por el maestro Mateo y su taller ${ }^{30}$ en torno a 1200. Cuando Sanclemente es promovido a la sede compostelana la antigua sillería no se compadece con sus pretensiones ya que deseaba tener su silla en el centro de la cabecera, precisamente donde se encontraba la puerta de acceso al recinto del coro. El subterfugio que utiliza para llevar a cabo su pretensión era acabar con las protestas del chantre cuando el prelado asistía al coro, pues al ocupar su silla obligaba a todos los canónigos de ese lado a retroceder un asiento. Las presiones del arzobispo debieron de ser tan fuertes que el 2 de septiembre de 1594 el cabildo acordó31: "que se alargase el coro por su parte posterior para que se pudiesen colocar algunas sillas más" y, para darle una solución idónea, se convocó una reunión de escultores entre los que se encontraban Juan de Angés y Juan Bautista Celma, conocidos colaboradores de Sanclemente en sus intervenciones en la catedral de Ourense. Se decide encargar unas muestras de las sillas a añadir y el arzobispo, por su cuenta, encarga otras sin notificarlo al cabildo quien, al saberlo, parará su intromisión.

La disputa entre el cabildo y el arzobispo por mantener o derribar el coro medieval va en aumento y, finalmente, el 20 de julio de 1599 aquél decide suprimir la puerta de la cabecera: "para effecto que en el medio del coro se haga la silla arçobispal y que las demás sillas se hagan en la mejor traza que pareciere". El viejo coro pétreo quedaba condenado a desaparecer de inmediato y el arzobispo porfiaba ante las dudas del cabildo a la iluminación en el nuevo coro asegurándole que tendría incluso más luz que el medieval. Lo que Sanclemente se callaba era que para lograrlo había que modificar el sistema que permitía el balanceo del Botafumeiro e intervenir en el cimborrio.

Castellá Ferrer" ${ }^{32}$ que alcanzó a ver el conjunto mateano, cuando se derribó escribió: "Se ha desecho el más lindo coro antiguo que avía en España". Las piezas pétreas desmontadas del viejo coro se utilizaron, en su mayoría, en las obras que en los primeros años del siglo XVII se realizaban en la catedral compostelana: fachada de la Puerta Santa, alguna figura se aprovechó como imagen de culto, pero la mayoría sirvieron de material de construcción en las obras en curso: muchas en la escalinata del Obradoiro, relleno del patio y crujías del claustro y edificios anejos, entre otras. Unas pocas salieron de la catedral y se emplearon en diferentes lugares y usos por lo que un reducido número han terminado, por ejemplo, en la fuente de san Pedro de Vilanova, -Vedra. A Coruña-, o en el crucero de Marantes, -Santiago, o en las colecciones del Museo Arqueológico Nacional, en Madrid.

La reutilización de los sillares del coro pétreo en las obras en curso en la catedral en los primeros años del siglo XVII permitió que desde los últimos del XIX comenzaran a recuperarse, proceso que se intensificó con las intervenciones realizadas a lo largo del siglo $\mathrm{XX}$ en diferentes puntos de la catedral compostelana. Su acumulación en los almacenes de la iglesia favoreció su estudio por parte de José Manuel Pita Andrade y Manuel Chamoso Lamas, quienes llegaron a reconstruir dos sitiales; los posteriores hallazgos de nuevas piezas y pacientes estudios permitieron a los profesores Ramón Otero Túñez y Ramón Yzquierdo

${ }^{29}$ López Ferreiro, 1906a: 179. Bonet Correa, 1966: 134-136. Vila/García, 1993c: 128-129. Vila Jato, 1993a: 34-36.

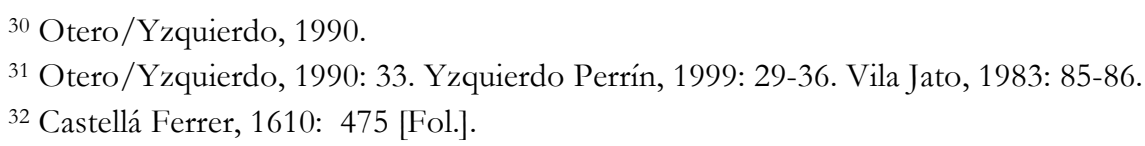




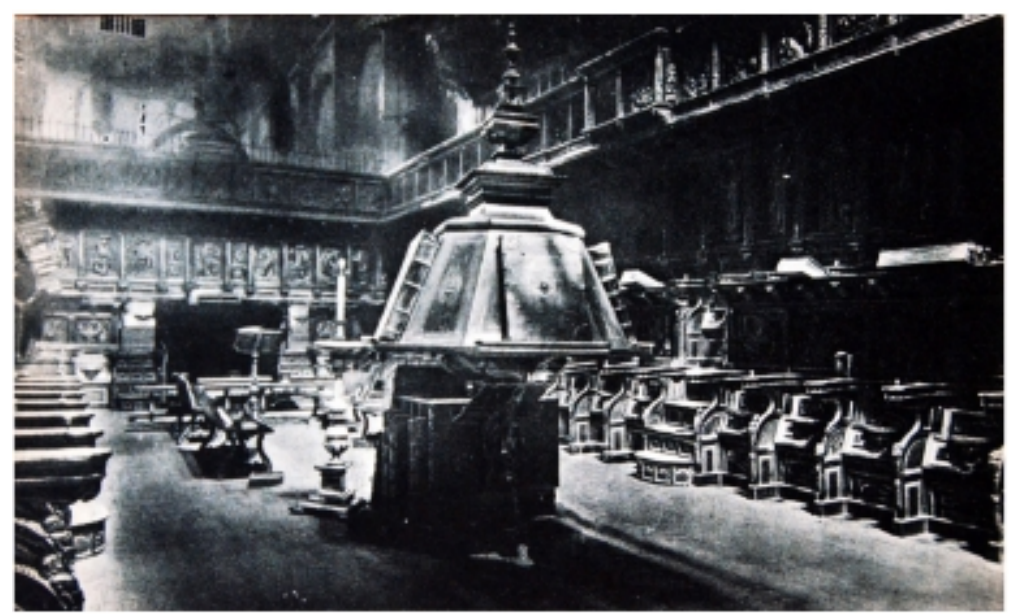

Fig. 6.. Vista general del coro de la Catedral de Santiago en su emplazamiento original. Foto de hacia 1940. (Foto Archivo Yzquierdo).

Perrín reconstruir en una nueva sala del Museo de la Catedral la mayor parte de la sillería alta $^{33}$.

Como había ocurrido con la renovación del coro de la catedral de Ourense al derribo del coro medieval compostelano le sucede la firma del contrato de talla de otro nuevo ajustado a las disposiciones trentinas, se cuida en especial que la silla del obispo ocupe un lugar preeminente que coincide con el centro del testero (Fig. 6). El contrato se firmó el 2 de septiembre de 1599 con los escultores Juan Davila y Gregorio Español, quienes trabajaron en ella hasta el 11 de julio de 1608, fecha en la que se cuentan las sillas y se pagan ${ }^{34}$. Este coro cumplió su función hasta mediados del siglo XX.

En abril de 1912 el cabildo catedralicio, que hacía poco había visto reducir el número de sus miembros, pretende trasladar el coro, situado en los primeros tramos de la nave central, a la capilla mayor. Encargó el oportuno proyecto al arquitecto Velázquez, quien lo presentó el primero de noviembre de 1915 pero su inesperada muerte paralizó su ejecución. De nuevo, en julio de 1940 el arzobispo, Tomás Muniz Pablos, pide al cabildo que se pronuncie sobre la conveniencia de trasladar el coro a la capilla mayor, idea que éste respaldó, pero a la que se opuso la Comisión Provincial de Monumentos de A Coruña y la Real Academia de San Fernando, institución que, sin embargo, terminará por aceptar su retirada. Don Jesús Carro, erudito sacerdote y miembro, antes de la guerra civil, del Instituto de Estudios Gallegos, en carta dirigida a Chamoso Lamas el 17 de octubre de 1942 da por condenado el coro compostelano, pues le consta que el cabildo y el arzobispo cuentan con el respaldo del Jefe del Estado pues, al parecer, pretendían convertir la catedral en un santuario capaz para grandes concentraciones de fieles. En mayo de 1944 la Dirección General de Bellas Artes ordena retirar una parte del coro, ya parcialmente desmontado. Su final era inminente ${ }^{35}$. Al no disponer la catedral de un espacio suficiente para su montaje se trasladó al coro alto del cercano monasterio de san Martín Pinario, de donde se trasladó al presbiterio de la iglesia de Sobrado dos Monxes, -Sobrado. A Coruña-. Aquí permaneció hasta 2003 en que de nuevo se trajo al coro alto de san Martín Pinario, donde fue restaurado y vuelto a montar, aunque no en su totalidad.

La clausura de la puerta del testero del coro medieval al colocar ante ella la silla del prelado suscitó en el cabildo el temor a que el recinto coral recibiese menos luz, recelo que se

\footnotetext{
33 Otero/Yzquierdo, 1990. Yzquierdo Perrín, 1999.

${ }^{34}$ Chamoso Lamas, 1950: 208-215. Vila Jato, 1983: 85-104. Rosende/ Suárez, 2004: 15 y ss.

35 Yzquierdo Perrín, 2004: 34-37. Rosende/Suárez, 2004: 38-45.
} 


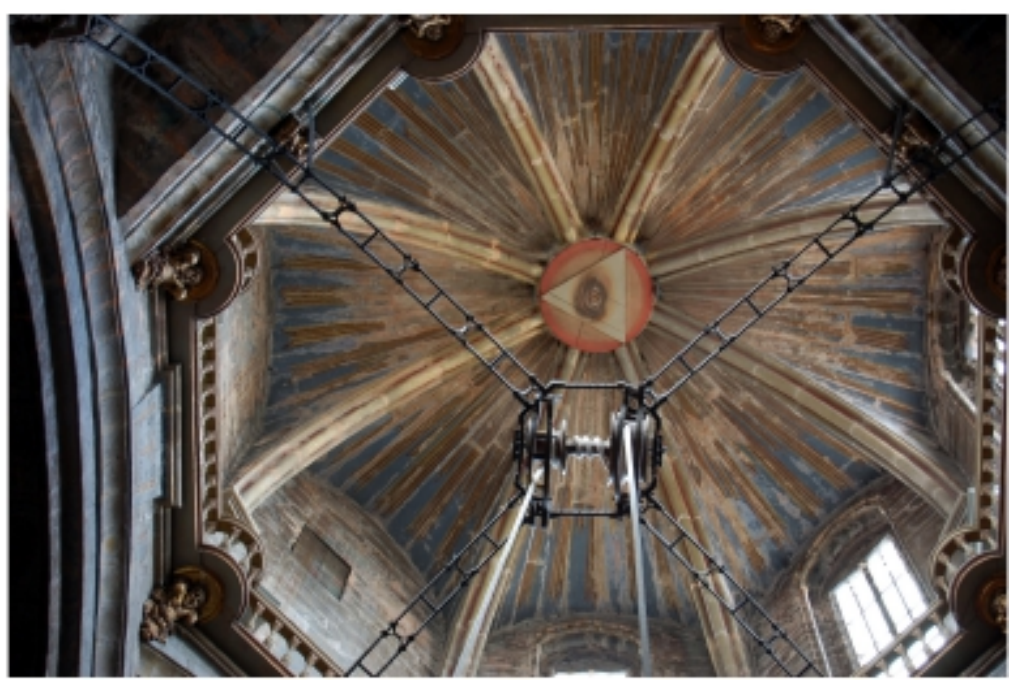

Fig.7. Cimborrio gótico de la Catedral de Santiago y poleas para el vuelo del Botafumeiro. (Foto Archivo Yzquierdo).

mantuvo cuando se decidió hacer uno nuevo. Sanclemente contestó ${ }^{36}$ : "que porque el coro se hiciese... se obligaba y obligó de que daría más luz y claridad que al presente hauía en el coro, y que no quedando, su Señoría a su costa volvería a reedificar su silla y todo lo que fuese necesario para que el coro tuviese tanta luz y claridad y más que al presente tiene". La porfía probablemente se fundamentaba en otra intervención que tal vez tenía in mente y, al no poder desarrollarla en vida, encargó al cabildo que la llevara a cabo tras su muerte, lo que se hizo al mes de su fallecimiento.

Al comienzo del acta del cabildo ${ }^{37}$ del 24 de mayo de 1602 se invoca a Sanclemente como persona: "de buena memoria que esté en el cielo" y se hace constar su idea de: "lo mucho que convenía que las rejas de la Capilla mayor y las del Coro se dorasen, y el cimborio se limpiase, dorase y asease y juntamente se quitasen las bigas del incensario y hiciese algún ingenio como estubiese mas galán y vistoso". En resumen, acuerdan limpiar y pintar el cimborrio, dorar algunos de sus elementos, rasgar las ventanas y colocar en ellas vidrios incoloros y, sobre todo: "que se quitasen las traves o vigones grandes que atraviesan el cimborio en que está puesta la polea para el incensario porque quitan mucha luz al coro y afean el cimborio". Pero como no quieren prescindir del Botafumeiro acuerdan que: "se hiciese un ingenioso artificio de quatro yerros que saliesen de las cuatro esquinas de sobre los capiteles de los cuatro postes principales del crucero". Para su diseño recurrieron a Juan Bautista Celma que hizo un: "modelo de madera por el cual se había de labrar en Vizcaya el ingenio o artificio de yerro para el incensario". Su traslado a Galicia se haría por mar, a pesar de que eran conscientes de los riesgos que afrontaban. El ingenio sigue en uso para el balanceo del singular y admirado Botafumeiro a lo largo del crucero catedralicio (Fig. 7).

\section{Otras intervenciones en la Catedral de Santiago}

Además de tan importantes actuaciones en la catedral compostelana el prelado impulsó otras que buscaban solucionar algunas deficiencias o promover nuevas prácticas devocionales. Su observación de lo que ocurría en el templo y su celo pastoral le llevaron a intentar que durante la celebración de los oficios litúrgicos no hubiera el griterio que provocaban tanto los peregrinos como el resto de los fieles. Para ello dotó a un "capellán del

\footnotetext{
36 López Ferreiro, 1906a: 385.

${ }^{37}$ López Ferreiro, 1906b: 218-221.
} 
Fig.8. Relicario de Sanclemente. Atribuido a Duarte Cedeira, el Mozo. Hacia 1594 (Foto Archivo Yzquierdo).

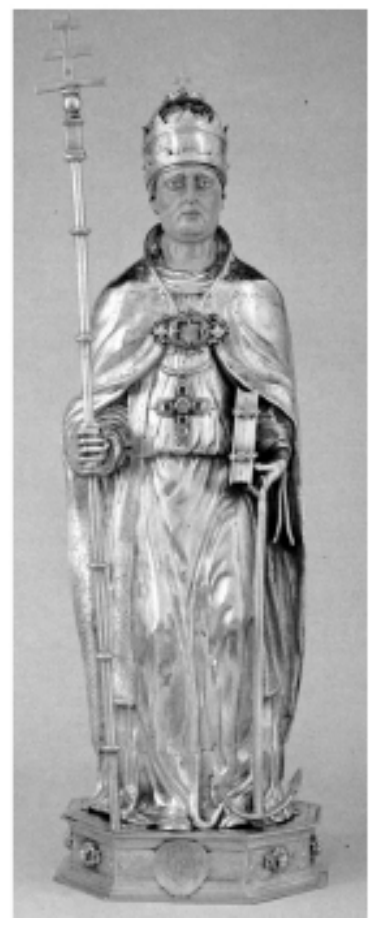

silencio",38, quien se encargaría del orden durante las ceremonias. En su testamento, otorgado el 30 de agosto de 1600, dice que: "para servicio de Nuestro Señor y para que con mayor devoción se celebre y oyga el oficio divino en esta Santa Iglesia y aya mayor silencio durante... las horas canónicas y mientras los predicadores estuvieren en el púlpito... y las misas cantadas... un Sacerdote mayor de quarenta años y con sobrepelliz y un sceptro de plata en la mano" recorra la catedral y claustro imponiendo silencio.

El arzobispo compostelano don Gaspar de Ávalos ${ }^{39}$, 1542-154, natural de Guadix, acompañó a Carlos V en 1543 en su viaje a Alemania y Flandes. El arzobispo de Colonia le regaló varias reliquias, entre ellas la cabeza de santa Florentina ${ }^{40}$, para la que en 1594 el cabildo encargó un relicario de busto a Jorge Cedeira, o Mozo, quien sigue el modelo utilizado por su padre, Jorge Cedeira, el Viejo, en el de santa Paulina, aunque con un estilo manierista e incluye en su basamento el escudo del arzobispo Sanclemente. En consonancia con la religiosidad del momento las reliquias adquirieron relevancia y durante su episcopado llegaron varias, desde diferentes poblaciones, a la catedral compostelana ${ }^{41}$. En relación con estas prácticas devocionales destaca la dotación que el prelado realizó el 10 de septiembre de 1594 para establecer la festividad de Sanclemente y el regalo de una pareja de candelabros de plata, adquiridos en Granada, el 5 de diciembre. Probablemente con este motivo donó al tesoro de la catedral una figura de plata dorada y con esmaltes del citado santo ${ }^{42}$ que lleva en su pecho una reliquia traida de Roma (Fig. 8). Su confección se atribuye a Duarte Cedeira, el Mozo, que colaboró con Celma en la realización de algunas esculturas para los púlpitos de la catedral ${ }^{43}$.

38 López Ferreiro, 1906a: 353-354; 1906c: 212-213. González García-Paz, 1993: 275-276 (Documento XIII. Testamento de la buena memoria....).

${ }^{39}$ Cebrián Franco, 1997: 179-182.

40 Pérez Costanti, 1930: 112-114. Yzquierdo Peiró, 2015: 509-510.

${ }^{41}$ López Ferreiro, 1906a: 354-357.

42 Dotación de la fiesta de San Clemente, y aniversario que fundó su señoría el señor Arcobispo Don Iuan de San Clemente Arçobispo de Santiago.(1600),Valladolid. Pérez Costanti, 1930:107-108. Yzquierdo Peiró, 2015: 507-508.

${ }^{43}$ Gallego de Miguel, 1963:119-138. Vila Jato, 1983: 33-43. 
Por último, en el citado testamento de don Juan de Sanclemente ${ }^{44}$, deja diferentes cantidades de dinero a la catedral y algunas de sus capillas, entre las que destacan las de san Juan y san Fructuoso que albergaban sendas parroquias. De la primera dice: "Item mando a la Capilla del Señor San Juan Evangelista, sita en esta Santa Iglesia para que se haga mayor o para lo que mas hubiere menester dozientos ducados", ampliación que se llevó a cabo a mediados del siglo XVIII y su autor, seguramente, fue Simón Rodríguez. Quizá esta limosna haya que relacionarla con el hecho de que en ella fue enterrada su hermana doña María, cuya lápida permanece en su muro derecho ${ }^{45}$. Igualmente "mando a la capilla de San Fructuoso para que se ponga una reja a la entrada que sea de yerro dorada y para lo que mas tuviere necesidad quatrocientos ducados", esta capilla fue derribada a finales del siglo XVII, junto con la de san Andrés, para construir la del Pilar ${ }^{46}$.

Intervenciones de Sanclemente fuera de la Catedral de Santiago.

No acaban en la catedral compostelana las intervenciones de mecenazgo, en especial el arquitectónico, de don Juan de Sanclemente, sino que se extienden a otros edificios de la ciudad y de otras poblaciones, sin olvidar a su natal Córdoba. Según Jerónimo del Hoyo ${ }^{47}$, visitador de la diócesis en 1607: "Mandó y dio ochocientos ducados para hacer la capilla mayor de la iglesia de Santa Susana", que hoy nada conserva de tal ampliación ${ }^{48}$ al haberse realizado importantes modificaciones en los siglos posteriores.

Tampoco pueden identificarse las obras que llevó a cabo en: "las casas arçobispales", que su biógrafo Sanz del Castillo ${ }^{49}$ precisa del siguiente modo: "Reedificó las Casas Arzobispales: la Sala de Audiencia, y vivienda del Provisor", actuaciones que no afectaron a las partes medievales del palacio, de las que no se tienen más referencias ni queda nada tras las importantes reformas del siglo XVIII. Quizá en relación con esta intervención en el palacio haya que situar la supresión de los soportales y tiendas que había ante él y la fachada norte de la catedral acordada en 1586, es decir, antes de su llegada a la sede, espacio también muy cambiado en los siglos XVIII y XIX.

Mayor trascendencia tuvo la tercera de las actuaciones impulsadas por el prelado a las que se refiere el citado Jerónimo del Hoyo, quien afirma que dio mil ducados al cabildo: "para allanar y enloçar la Quintana y haçer las escaleras y terraplenes que están en la dicha Quintana", obras que inician la urbanización de un espacio básico en el urbanismo compostelano que en el siglo XVII fue objeto de magníficas intervenciones arquitectónicas. Por último, hizo una cárcel eclesiástica ${ }^{50}$ : "para evitar la mezcla con los legos", en la que cumplirían sus penas: "a no ser que se tratase de delito que mereciese pena de muerte, deposición o degradación", estaba situada en "el quarto nuevo da la dicha Santa Yglesia o torre del", lo que hizo precisa una concordia con el cabildo en 1597.

Durante su arzobispado Sanclemente patrocinó numerosas obras y mejoras en construcciones diversas. Jerónimo del Hoyo ${ }^{51}$ dice que: "Reparó las fortaleças de Pontevedra, como Lantaño, Lobera y las demás", intervenciones que es necesario relacionar con los ataques y amenazas que a finales del siglo XVI sufría la costa gallega por parte de la flota inglesa y, en particular, de Drake. Durante uno de estos ataques las iglesias de santa María del Camino de Pontevedra y santa María de $\mathrm{Alba}^{52}$, próxima a esta ciudad, sufrieron tan

44 López Ferreiro, 1906a: 358-359; 1906c: 211-218. González García-Paz, 1993: 7-79; 1993: 274-285. (Documento XIII). Véase en particular la p. 276.

45 Fernández/Freire, 1885: 147. Folgar de la Calle, 1989: 109-114.

46 Ríos Miramontes, 1986: 165 y ss.

${ }^{47}$ Hoyo, 1607: 32-33. Sanz del Castillo, 1769: 98. López Ferreiro, 1906a : 344, 346 y 352.

48 Sobre esta iglesia y su emplazamiento: Carro García, 1961-1962: 241-247.

${ }^{49}$ Sanz del Castillo, 1769: 98. Sobre las intervenciones en este palacio: Yzquierdo Perrín, 2000: $20-89$.

${ }^{50}$ Sanz del Castillo, 1769: 98. López Ferreiro, 1906a: 352.

51 Hoyo, 1607: 32. López Ferreiro, 1906a: 344.

52 Pérez Costanti, 1930: 336-337. González García-Paz, 1993: 59-61. Goy Diz, 1998: 602. 
Fig.9. Santiago de Compostela . Timpano gótico de Santa Maria "a Nova" y escudo episcopal de Sanclemente (Foto Archivo Yzquierdo).

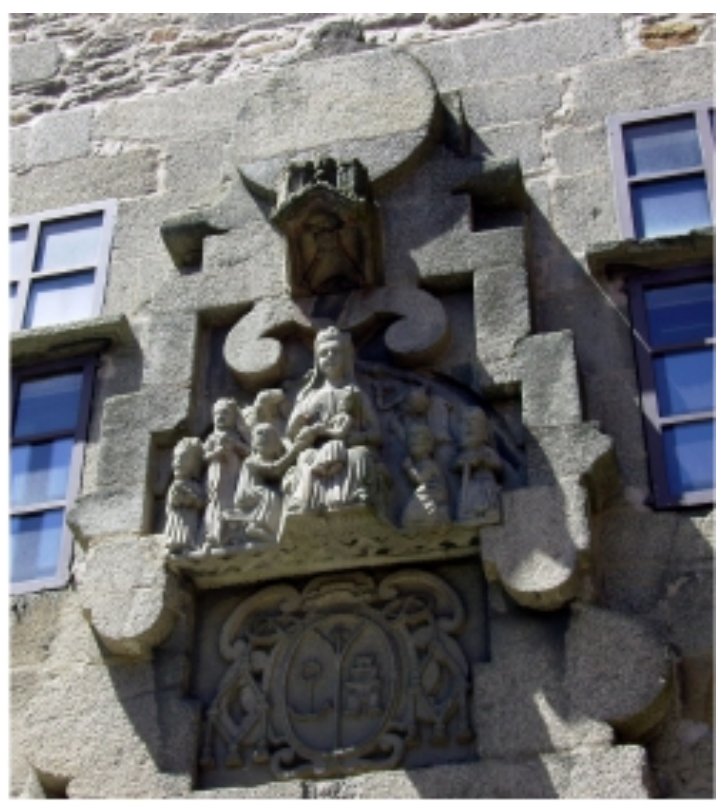

graves destrozos, que el arzobispo acudió de inmediato y el 19 de marzo de 1595 contrató con Mateo López su reconstrucción. De la primera dice Sanclemente en el contrato que estaba: "mal edificada y mal trazada, como nos constó por vista de ojos" y las obras se prolongaron hasta los primeros años del siglo XVII; la segunda, se encontraba tan arruinada que incluso se trasladó de emplazamiento y en el nuevo edificio se reutilizaron las piedras de la anterior. Como testimonio del mecenazgo del prelado se colocó sobre la puerta principal y encima del arco triunfal su escudo junto con su nombre. Otras muchas parroquias, hospitales y conventos se beneficiaron de la generosidad de Sanclemente, entre los que destaca la ayuda a la construcción del convento de santo Domingo de Betanzos ${ }^{53}$.

En el ya citado testamento que Sanclemente ${ }^{54}$ figura una larga relación de mandas a iglesias, monasterios, conventos, asociaciones religiosas, hospitales y otras instituciones así como numerosas personas de múltiples poblaciones, sin olvidarse de los pobres, criados y quienes en algún momento le sirvieron.

\section{Mecenazgo de don Juan de Sanclemente en Córdoba}

Aunque la mayor parte de la vida de don Juan de Sanclemente transcurrió lejos de su ciudad natal, nunca se olvidó de su origen y, desde Santiago de Compostela, ejerció un efectivo mecenazgo que se inicia con sus generosas aportaciones para construir en la iglesia de san Pedro, hoy basílica menor ${ }^{55}$, una capilla para las reliquias de los mártires que se habían encontrado en 1575 así como dinero para labrar un arca de plata para guardarlas. La fábrica actual es barroca por las reformas efectuadas a mediados del siglo XVIII y el arca de las reliquias tampoco es la costeada por el prelado, sino de finales de la misma centuria. Sin embargo sí se mantiene en su emplazamiento original la reja costeada por Sanclemente, en cuyo remate todavía se encuentra su escudo y capelo arzobispales. Igualmente envió mil ducados para la obra de la capilla mayor y coro de la misma basílica.

53 González García-Paz, 1993: 59-61. Pardo Villar, 1930: 16-21, 40-45, 59-63, 83-87 у 112-120, respectivamente.

54 López Ferreiro, 1906a: 358-359; 1906c: 211-218. González García-Paz, 1993: 7-79; 1993: 274-285 (Documento XIII).

55 Sanz del Castillo, 1769: 99. López Ferreiro, 1906a: 359. González García-Paz, 1993: 58. Información e imágenes en cordobapedia.wikanda.es y wikipedia.org [11-01-2016]. 


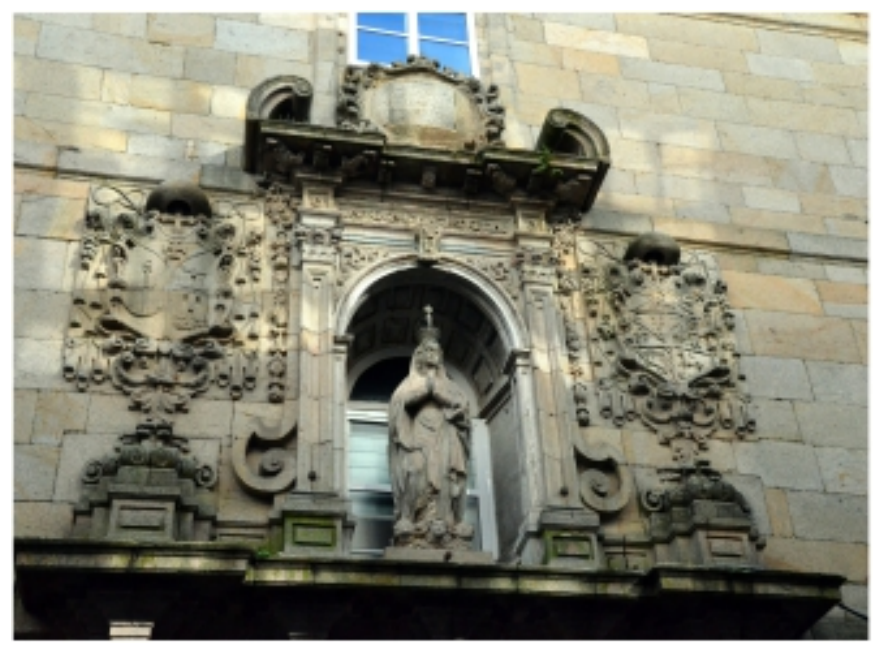

Fig.10. Santiago de Compostela . Por menor de la portada del Colegio de Huerfanas, a la izquierda escudo episcopal de Sanclemente. (Foto Archivo Yzquierdo).

Por su parte a la catedral cordobesa le envió tres mil ducados para ayudar a la obra del coro y de la capilla mayor. Otros dos mil ducados los destinó para que con su renta se protegiera a expósitos y, finalmente, creó becas para que sus parientes cordobeses pudieran estudiar en la Universidad de Salamanca.

En el testamento Sanclemente tampoco se olvidó ni de su familia ni de diversos conventos cordobeses. Por ejemplo, a su hermana doña María de Santa Ana, religiosa en santa María de Córdoba, manda que: "se le den quatrocientos ducados que bien sabe como los ha de repartir. Digo se le den... si fuere viva al tiempo que yo muriese y si no lo fuere sean para mis herederos", ya que sabe que otros: "parientes y deudos... tienen necesidad y a otras personas a quien tengo obligación". Proporcionalmente el capital destinado a misas en sufragio de su alma es menos cuantioso, y tampoco olvida los conventos cordobeses de Nuestra Señora del Carmen Calzado y Descalzo, entre otras iglesias y capillas de diferentes ciudades.

\section{Don Juan de Sanclemente y la formación de la juventud.}

Tras la disciplina eclesiástica y la implantación y estricto cumplimiento de las disposiciones del Concilio de Trento la mayor preocupación de don Juan de Sanclemente fue la formación no sólo del clero, sino también de los niños y niñas, en especial de los más necesitados a quienes dedicó sus más importantes fundaciones. El detonante, además de lo mandado por Trento con respecto a la formación del clero, pudo ser el conflicto surgido en 1595 con los acólitos y mancebos de coro ${ }^{56}$ de la catedral compostelana que llevó al cabildo a cerrar el seminario en el que vivían y devolverlos a sus domicilios. Las decisiones que a partir de entonces tomó el arzobispo en el ámbito de la educación quizá movieron a los capitulares a reabrir el clausurado seminario antes de terminar 1599.

\section{El arzobispo Sanclemente, la Compañía de jesús y la enseñanza.}

El 8 de junio de 1595 el arzobispo Sanclemente firmó un convenio con el provincial de la Compañía de Jesús para que en su fundación compostelana se estableciera una escuela de niños ante: "la gran necesidad que los niños tienen de ser instruidos y enseñados desde su tierna edad en las cosas de la Santa fee católica y en buenas y loables costumbres y de tener maestros que se las enseñen, juntamente con leer, escribir y contar y el medio para esto más eficaz y de más importancia era instituir una escuela"57. La dotó con 3200 ducados, capital suficiente para mantener a dos maestros, y a pesar de que el cometido no le agradaba en exceso a los jesuitas lo aceptaron por la simpatía con que el prelado los había acogido y

\footnotetext{
${ }^{56}$ López Ferreiro, 1906a: 335.

57 González García-Paz, 1993: 64-66; 1993: 270-273 (Escritura de fundación y clausulas de contrata... Doc. XII). Sanz del Castillo, 1769: 97.
} 


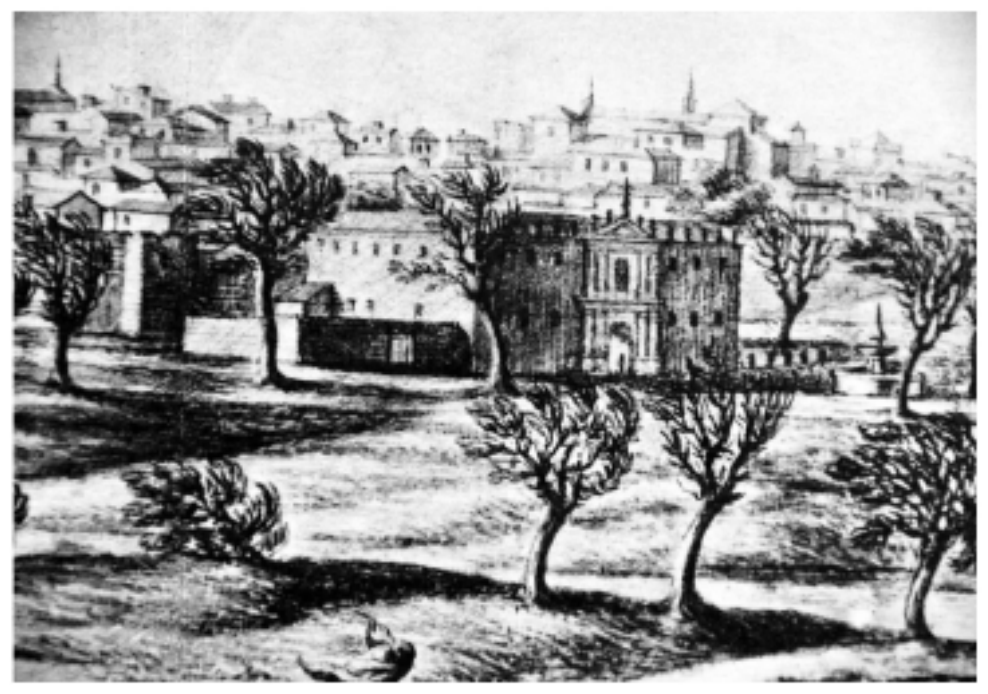

Fig.11. Pier Maria Baldi, 1669. Por menor de la vista de Santiago de Compostela con el Colegio de Sanclemente en primer plano. (Foto Archivo Yzquierdo).

apoyado desde sus años de obispo de Ourense y en particular en la fundación del colegio de Monterrey. Además, sabían que pretendía traspasar al colegio compostelano de la Compañía las aulas universitarias de gramática ${ }^{58}$. En 1596 comenzó a funcionar la escuela con gran número de alumnos. El prelado estaba tan satisfecho con el éxito de su iniciativa que aumentó en mil ducados la dotación inicial y decidió que los docentes fueran jesuitas, no seglares, lo que suscitó el recelo del ayuntamiento y de los padres de los niños menos necesitados en 1597. De esta colaboración de Sanclemente con los jesuitas queda en la portada posterior del edificio que fue su Casa de Ejercitantes, actual sede universitaria en Mazarelos, el escudo del prelado debajo de una epifanía gótica con marco barroco compostelano de Simón Rodríguez ${ }^{59}$ fechable en 1734 (Fig. 9).

La colaboración entre el arzobispo y los jesuitas se extendió también a los estudios de Gramática o de Humanidades, origen de la Universidad de Santiago a partir de 1526. Los jesuitas se habían especializado en estas materias por lo que algunas universidades encomendaron a la Compañía su enseñanza. Sanclemente era partidario de que también en Santiago se encargaran de ellas ${ }^{60}$ pero a pesar de su directa intervención en el claustro de la Universidad y de lograr que lo aceptara, el proyecto fracasó. Lo que sí pudo establecer en el colegio de la Compañía fue una cátedra de teología moral ${ }^{61}$ materia que, por otra parte, se impartía desde 1581, gracias al esfuerzo y tesón del arzobispo Blanco, su predecesor en la sede. El interés de Sanclemente en esta materia radicaba en su contenido, orientado a que los clérigos o quienes se preparaban para serlo supieran resolver los casos de conciencia y confesión.

\section{Colegio para doncellas pobres.}

Al tiempo que el arzobispo consigue que los jesuítas acepten establecer una escuela para niños se afana, quizá presionado por su hermana, doña María de Torquemada, en organizar y establecer otra para niñas. Con este fin en agosto de 1597 adquiere una casa, llamada de la Troya, en la calle de Callobre, que pertenecía al cabildo; en 1601 compra otra casa contigua con objeto de dedicarlas a colegio en el que: "se recogiesen algunas doncellas pobres y de buena vida y costumbres y allí les enseñasen la doctrina cristiana y otros lavores de por casa y les doctrinasen para que después de enseñadas pudiesen servir en casas honradas", según

58 Sanz del Castillo, 1769: 97. López Ferreiro, 1906a: 358-359. Pérez Costanti, 1925: 387. Rivera Vázquez, 1989: 79 y 230-235.

${ }^{59}$ Caamaño Martínez, 1958: 336-337. Folgar de la Calle, 1989: 114-118.

${ }^{60}$ Vázquez Martínez, 1971: 178-186. Rivera Vázquez, 1989: 241-242.

${ }^{61}$ Sanz del Castillo, 1769: 97. Rivera Vázquez, 1989: 265. 


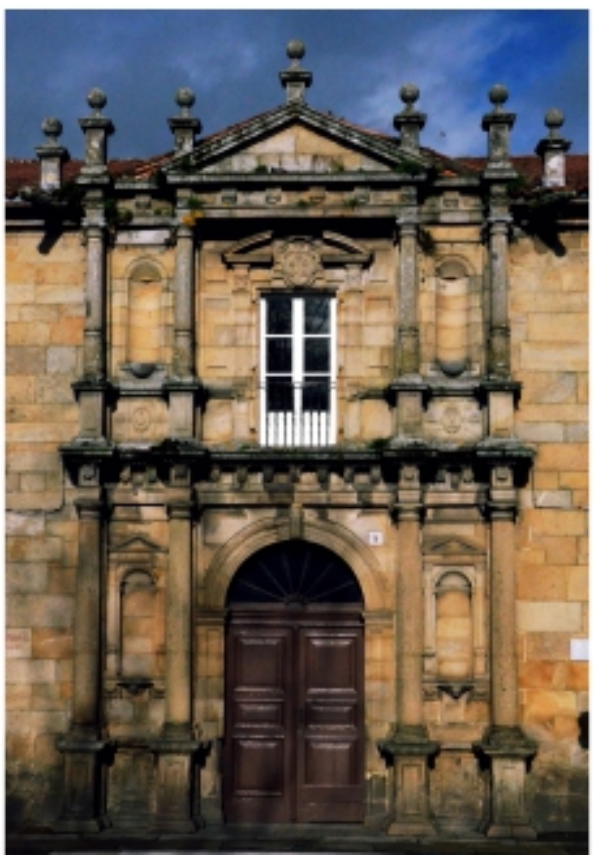

Fig.12. Portada del Colegio de Sanclemente de Pasantes.. (Foto Archivo Yzquierdo).

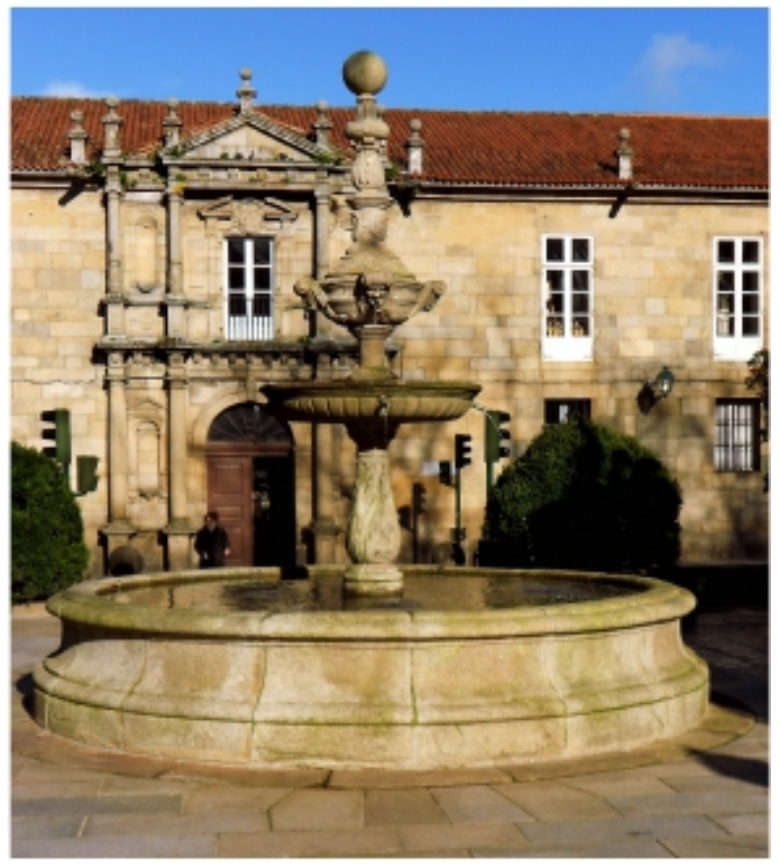

Fig.13. Santiago de Compostela. Fuente y portada del Colegio de Sanclemente. (Foto Archivo Yzquierdo).

el acta fundacional, fechada el 23 de marzo de 1600, la dota con un capital suficiente para su pervivencia que administraría el cabildo, depositario de los títulos oportunos. En él residirían dieciocho huérfanas y varias pupilas ${ }^{62}$. La fundación pervive y se conoce como Colegio de las Huérfanas, denominación que ha dado nombre a la calle en la que se levanta, aunque sus edificios tampoco son los originales, sino los que construyó el arzobipo fray Antonio de Monroy ${ }^{63}$ en los comienzos del siglo XVIII para remediar la ruina de los viejos, al tiempo que dictó nuevas disposiciones relativas a la vida del colegio similares a las que regían en los conventos de clausura. El colegio conserva un par de escudos de Sanclemente: uno, sobre la puerta de su iglesia; otro, en la portada del colegio en medio de una decoración dieciochesca y forma pareja con el de Monroy (Fig. 10). En el interior guarda un retrato al óleo del arzobispo Sanclemente con un breve epígrafe: "Don Juan de Sanclemente, arzobispo de Santiago, fundador de este colegio", pintado por Pedro Antonio Vidal ${ }^{64}$ en 1779, es decir, cuando se terminaban los nuevos edificios.

\section{Colegio de Sanclemente de Pasantes.}

La más importante fundación docente del arzobispo Sanclemente fue también la más meditada y la perfila en su testamento, por lo que fueron sus albaceas quienes la llevaron a cabo, es la única que mantiene su edificio original y que, a pesar de los siglos transcurridos, sigue siendo un centro de enseñanza. La idea original del prelado probablemente fue dar cumplimiento a lo tratado en la sesión XXII del Concilio de Trento ${ }^{65}$ que, tras las disposiciones sobre el sacrificio de la misa, continúa con el "Decretum de Reformatione", relativo a la formación del clero.

${ }^{62}$ Sanz del Castillo, 1769: 97. Anónimo, 1883: 42-43, 52-53 y 59-60, respectivamente. López Ferreiro, 1906a: 344-346. González García-Paz, 1993: 62-63.

${ }^{63}$ Ríos Miramontes, 1986: 337-348. Barral Iglesias, 1998: 87-110.

${ }^{64}$ Murguía, 1884: 233. Repite lo dicho por Murguía: Couselo Bouzas, 1932: 651; 1950: 39. Andrés Ordax, 2015: 80

65 Sacrosancti et Oecumenici Concilii Tridentini,... canones et decreta, 1762: 239-250. 
Este anhelo es el que le impulsa a solicitar al papa Clemente VIII que le permita disponer de treinta mil ducados para fundar un colegio o seminario en Santiago, Salamanca, Alcalá o Córdoba, como consta en el primer codicilo de su testamento, fechado en Santa Eugenia de Ribeira el 11 de octubre de 1601, en el que manda que tales ducados: "se empleen en fundar un seminario y collegio, según el fin que pretende el Santo Concilio de Trento, el qual se funde y edifique en la nuestra Ciudad de Santiago, en la Universidad de Salamanca, en la de Alcala de Enares o en la ciudad de Cordova donde yo soy natural, en la parte donde les pareziere mas cómoda a mis testamentarios", y que en él: "se crien y estudien mancebos estudiantes, que aprovechen en virtud y Letras". El codicilo fue hecho ante su secretario y notario apostólico don Pedro Sanz del Castillo quien, junto con su sobrino, don Juan de Sanclemente, arcediano de Nendos, como sus albaceas, cumplieron su voluntad y decidieron que se fundara y levantara extramuros de Santiago, aunque en un solar inmediato a las murallas y en él dotaron dieciocho becas destinadas a estudiantes de las diócesis que pagaban los votos de Santiago. El nuevo colegio se regiría por las mismas constituciones que el de san Bartolomé de Salamanca ${ }^{66}$.

Este colegio, tercero de los compostelanos, era unos años posterior a los de Fonseca y San Jerónimo, por lo que se le denominaba "Colegio nuevo" y se destinó a "pasantes" o posgraduados que en él completaban su formación. La construcción del edificio ${ }^{67}$ se comenzó el 22 de agosto de 1605 y en 1607 todavía estaba en obras, según relata Jerónimo del Hoyo: "el Collegio que está en esta çiudad, extramuros della, començole su sobrino don Juan de Sanclemente y Godoy... y lo que hasta ahora está echo en el dicho collegio, con su huerta, jardines y fuentes es obra de muy gran principe" (Fig. 11). Aunque la autoría ${ }^{68}$ de las trazas del edificio se desconoce algunos opinan que podrían corresponder al jienense Ginés Martínez de Aranda, pero lo cierto es que en su construcción intervino Jácome Fernández, al menos desde 1609. Éste en diferentes documentos se titula: "Maestro de la obra de San Clemente", a pesar de serlo de la catedral.

El edificio, de planta cuadrangular, se organiza en torno a un sobrio patio central de doble alzado que articulan pilastras, entre las que se abren puertas y ventanas. El elemento ornamental más significativo son los escudos labrados en la planta alta a razón de dos por lado. En el exterior la fachada principal apenas rompe la linea general en la portada, (Fig. 12) organizada en su puerta, como un austero arco triunfal; en su conjunto, como un sobrio retablo en el que nunca se colocaron imágenes en sus hornacinas. Sobre la ventana del cuerpo alto rompe el frontón que la culmina el escudo del fundador. Ante ella, en la Alameda, todavía se encuentra la fuente que el ayuntamiento dotó con dos cornados de agua con la condición de que se situara ante el colegio para que diera servicio tanto a los colegiales como a los vecinos de las proximidades (Fig. 13).

El colegio empezó a funcionar en 1630 y se regía en sus comienzos por las constituciones del de San Bartolomé de Salamanca, pero ya en 1635 se hicieron unas constituciones propias $^{69}$. En él debían de vivir dieciocho colegiales, aunque nunca fueron, por razones económicas, más de ocho. Que fuera desde el inicio colegio mayor suscitó no sólo una rivalidad con el de Fonseca, sino un pleito que se sustanció en 1730 al decretar Felipe V que sólo éste tuviera esa consideración, lo que fue objeto de nuevas fricciones. A pesar de todo el colegio se mantuvo hasta 1808 , fecha a partir de la cual el edificio pasó por diferentes usos $^{70}$, entre los que cabe mencionar los de cuartel, cárcel, viviendas para familias y otras

${ }^{66}$ Sanz del Castillo, 1769: 96-97. López Ferreiro, 1906a: 358-359; 1906c: 211-218. González García-Paz, 1993: 67 y ss; 1993: 274-285 y 288-289, respectivamente (Documento XIII, Testamento de don Juan de Sanclemente; Documento XVI, Codicilio de 1601). Enríquez Morales, 2004: 31-35.

${ }^{67}$ Enríquez Morales, 2004: 31-35. Hoyo, 1607: 32. Goy Diz, 1996: 38-43.

${ }^{68}$ Bonet Correa, 1996: 127-131. Vila Jato, 1993b: 125-127. Goy Diz, 1996: 38 y 42. Enríquez Morales, $2004:$ $32-33$.

${ }^{69}$ González García-Paz, 1993: 7-79; 1993: 293-313 (Documento XX. Constituciones en latín de este Colegio de San Clemente, único de Passantes).

${ }^{70}$ Enríquez Morales, 2004: 35-39. Couselo Bouzas, 1928: 42 y ss. Cebrián Franco, 1997: 272-273. 


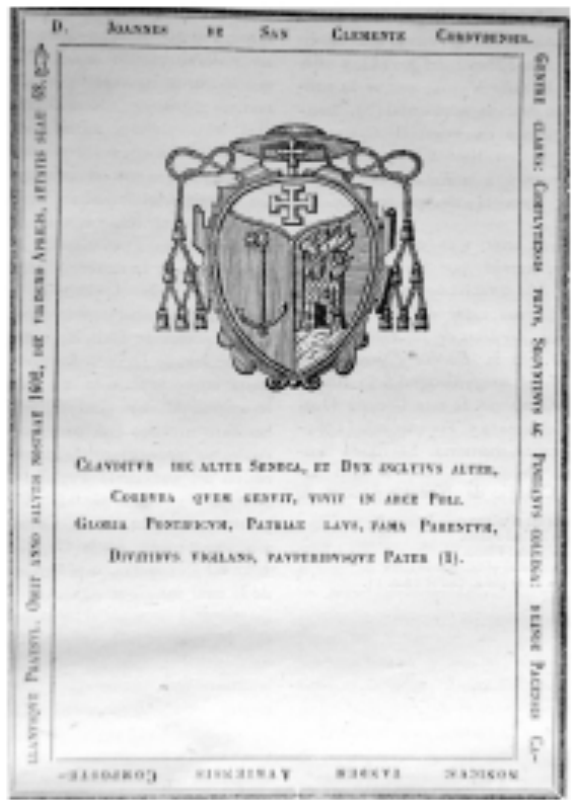

Fig.14. Lápida sepulcral del arzobisco don Juan de Sanclemente. Según: Fernández Sánchez/Freire Barriero (1880): Santiago, Jerusalén, Roma. I [T.], Santiago, p. 218. (Foto Archivo Yzquierdo).

personas, etc. mientras el arzobispo fray Rafael de Vélez insiste ante el rey para que le entregue el edificio del antiguo colegio con objeto de establecer un seminario conciliar. Tras invertir considerables cantidades en repararlo y adaptarlo al nuevo uso lo inauguró el 14 de octubre de 1829 y aquí permaneció el seminario hasta 1866, con el paréntesis entre 1835 y 1844 en que de nuevo fue cuartel.

En 1866 el edificio levantado a expensas de don Juan de Sanclemente era pequeño para el elevado número de aspirantes al sacerdocio que había, por lo que se sopesa la conveniencia o no de levantarle una segunda planta, solución que no convence al arzobispo, don Miguel García Cuesta $^{71}$, quien solicita a la reina Isabel II la permuta del edificio de San Clemente por el de san Martín Pinario, que se encontraba en un estado lamentable, materializándose el trueque el 11 de mayo de 1867. Al retornar el colegio de San Clemente a propiedad del Estado vuelve a albergar diferentes instituciones durante períodos más o menos prolongados: Archivo General de Galicia, Real Sociedad Económica de Amigos del País con sus escuelas y proyecto de creación de un Museo Arqueológico, Escuela de Artes y Oficios, Escuela de Veterinaria, Facultad de Derecho, Seminario de Estudios Gallegos y, desde 1939, sede del Instituto Femenino, actual Instituto Rosalía de Castro.

En julio de 1884 la Sociedad Económica de Amigos del País de Santiago ${ }^{72}$ conmemoró su primer centenario con diversos actos que se celebraron entre los días 19 y 26 de dicho mes. El 20: "se inaugurará, como obra de la Sociedad Económica, el Museo arqueológico central de Galicia que hace años la misma Sociedad trae en estudio y proyecto", también se abriría una exposición: "de los más notables trabajos desempeñados en estos años últimos por las escuelas de dibujo, modelado y labores de mujeres, que sostiene la Sociedad". En la apertura pronunció un discurso don Luís Rodríguez Seoane, publicado como anexo de "Galicia Diplomática". Sus salas se instalaron: "en los locales de planta baja, con dos salas altas en el lienzo Este del hermoso edificio de San Clemente, el breve tiempo no ha permitido la apertura de todas sus dependencias en las que hay que ejecutar obras de consideración; no obstante el Museo gallego, gracias a los esfuerzos de la Comisión y a la espontaneidad y patriotismo de las personas ilustradas se presenta, después de sólo quince días de trabajos,

\footnotetext{
${ }^{71}$ Cebrián Franco, 1997: 285-286.

${ }^{72}$ Los estatutos fundacionales de la Real Sociedad Económica de Amigos del País de Santiago habían sido aprobados por el rey Carlos III en el Real Sitio de San Ildefonso de La Granja el 23 de septiembre de 1784. Real Cédula de S. M.... en que se aprueban los Estatutos de la Real Sociedad Económica de Amigos del País de Santiago. (1787), Santiago.
} 


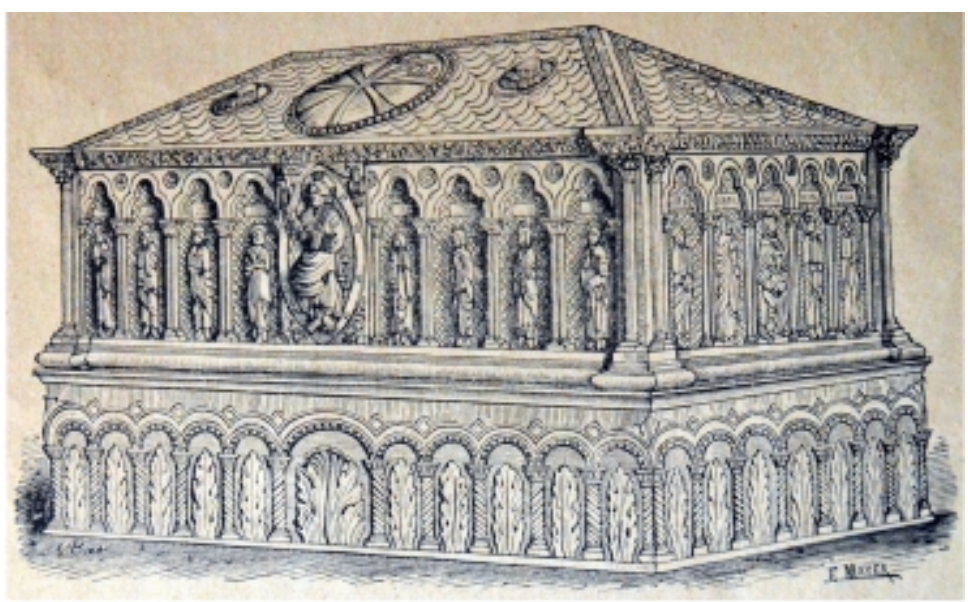

Fig.15. Santiago de Compostela.Unna de las reliquias del apostol Santiago sobre el basamento de bronce fundido de la lápida sepulcraldel arzobispo Sanclemente. Grabado de E. Mayer. Publicado por: López Ferreiro, a. (1891): Altar y cripta del apóstol Santiago. Compostela, p.33. (Foto Archivo Yzquierdo)

riquísimo en preciosidades de todo género" ${ }^{, 73}$. No se tienen mas noticias del museo, quizá porque la premura e impaciencia por abrirlo jugó en su contra. De él sólo queda un arco gótico, montado en una de las esquinas del claustro bajo, con una reja forjada entonces en cuyo dintel se lee: "Museo Arqueológico".

Entre tan diversos usos destaca que en 1909 fuera sede de la sección de Bellas Artes y Arqueología de la Exposición Regional Gallega ${ }^{74}$, que en aquel año se celebró y tuvo una gran importancia para el conocimiento y estudio del patrimonio artístico de Galicia. A partir de ella se incentivó el interés por las piezas arqueológicas y artísticas, algunas pasaron a engrosar los fondos de las escasas colecciones privadas que había; otras, sirvieron de inicio a los museos arqueológicos que comenzaron a surgir en diversas ciudades.

\section{Muerte de don Juan de Sanclemente.}

El arzobispo don Juan de Sanclemente falleció en el palacio arzobispal compostelano el 20 de abril de 1602 a los 68 años de edad, muerte que al decir de Sanz del Castillo ${ }^{75}$ : "Fue grande el sentimiento que huvo en la Ciudad y Arzobispado, y su muerte la más llorada que se sabe de Principe y Prelado alguno"; un poco más adelante sigue: "Enterróse junto a la Reja de la Capilla mayor debajo del Púlpito del Evangelio" y su sepultura se cubrió con una lápida de bronce (Fig. 14), reutilizada siglos más tarde para confeccionar el basamento (Fig. 15) sobre el que se colocó la urna de plata que guarda los restos del apóstol Santiago y sus discípulos Teodoro y Atanasio, decorado con una arquería ciega con hojas vegetales, que se fundió: "de la gran plancha que en otro tiempo cubría la sepultura del ilustre Arzobispo D.

\footnotetext{
${ }^{73}$ Rodríguez Seoane, 1884. Aunque en el programa de la Sociedad Económica se fija la inauguración el día 20, este semanario da cuenta de ella en su ejemplar del día anterior. En él aparece un artículo en el que se publica una circular que habían mandado a sus suscriptores "del exterior", así como la primera entrega relativa a los "Objetos expuestos en el Museo Arqueológico Gallego", de la que sólo vió la luz una segunda: Galicia Diplomática, II [T.], 46 [Núm.], pp. 341-344 y 47[Núm.], pp.345-346.

${ }^{74}$ Fariña Busto, 2010: 195-206. Alvarellos, 2009: 39-44 y 99-114.

75 Sanz del Castillo, 1769: 108-109.
} 
Juan de Sanclemente. Diríase que una especie de sino providencial trató de enlazar con la del Santo Apóstol la memoria de este insigne Prelado"76.

Apesar de haberse fundido se conoce su largo y encomiástico epígrafe así como un grabado que la reproduce ${ }^{77}$. Alrededor de su perímetro corría una inscripción identificativa de a quien pertenecía, mencionaba sus principales cargos y la fecha de la muerte. En el campo de la lápida casi la mitad superior la ocupaba su escudo, coronado por el capelo episcopal, y bajo él un largo párrafo laudatorio en latín que resumía su biografía y terminaba con frases encomiásticas. Su versión española decía: "Don Juan de Sanclemente, cordobés; de esclarecido linaje; primeramente colegial de Alcalá, de Sigüenza y de Valladolid, después canónigo de Badajoz, por fin prelado de Orense y de Santiago. Murió en el año 1602 de nuestra salvación, el día 20 de abril, a los 68 de edad. Yace aquí un segundo Séneca y un segundo Gran Capitán. Nació en Córdoba, vive en los alcázares del cielo. Gloria de pontifices, honor de la patria, lustre de sus padres, vigilante de los ricos, padre de los pobres".

${ }^{76}$ López Ferreiro, 1891: 32-33 y nota 1. Por su parte la urna de plata fue labrada en el taller compostelano de José Losada en 1886. Véase: Barreiro de V. V., 1888: 217-218.

77 Fernández/Freire, 1885: 288. Sanz del Castillo, 1769: 109. 
Bibliografía

Alvarellos, H.: Santiago, 1909. Centenario da Exposición Rexional Galega. Santiago. (2009).

Andrés Ordax, S.: El Colegio de Santa Cruz de Valladolid. Más de quinientos años de historia. Valladolid. (2015)

Anónimo;: "Fundación del Colegio de Doncellas huérfanas de Nuestra Señora de los Remedios". En: Galicia Diplomática, II [T.], 6, 7 y 8, [Núm.], Santiago, 12, 19 y 26 de agosto, (1883), pp. 42-43, 52-53 y 59-60, respectivamente.

Bande, E.: Episcopologio Ourensano. 1848-2004. Ourense. (2005).

Barral Iglesias, A.: "Colegio de doncellas huérfanas de Santiago de Compostela". En: IV Semana Mariana en Compostela, Santiago, (1998) pp. 87-110.

Barreiro de V. V., B.: "La santa cripta y la urna de las reliquias". En: Galicia Diplomática. Año III, 28 y 29 [Núm.], Santiago, 22 de julio, (1888), pp. 217-218.

Bartolini, D.: Apuntes biográficos de Santiago Apóstol el Mayor... Roma. (1885).

Bonet Correa, A.: La arquitectura en Galicia durante el siglo XVII. Madrid. (1996).

Caamaño Martínez, J. Ma.: "Seis tímpanos compostelanos de la adoración de los Reyes". En: Archivo Español de Arte, XXXI [T.], 124 [Núm.], Madrid, octubre-diciembre, (1958), pp. 336-337.

Carro García, J.: “Outeiro de santa Susana, castro y mámoa de Santiago de Compostela”. En: Homenaje al profesor Cayetano de Mergelina. Murcia, (1961-62), pp. 241-247.

Castellá Ferrer, M.: Historia del Apóstol de Iesus Christo Sanctiago Zebedeo, Patrón y Capitán General de las Españas. Libro IV. Madrid. (1610).

Cebrián Franco, J. J.: Obispos de Iria y arzobispos de Santiago de Compostela. Santiago. (1997).

Conde Cid, N.: La catedral de Ourense como imagen del Paraíso en la Edad Media: Arquitectura, cultura visual y espacio para la penitencia. Tesis doctoral. Universidad de Santiago. (2015).

Constituciones Synodales del Arzobispado de Santiago hechas por el Illustrisimo y Reverendisimo Señor Don Francisco Blanco... y mandadas imprimir de nuevo por Su Señoría Don Juan de Sant Clemente... en 16 de Mayo de 1601 años. (1601), Santiago.

Couselo Bouzas, J.: Fray Rafael de Vélezy el Seminario de Santiago. Santiago. (1928)

Couselo Bouzas, J.: Galicia artística en el siglo XVIII y primer tercio del XIX. Santiago. (1932)

Couselo Bouzas, J.: La pintura gallega. La Coruña. (1950)

Chamoso Lamas, M.: "El coro de la catedral de Santiago". En: Cuadernos de Estudios Gallegos, V [T.], XVI [Fasc.], Santiago, (1950), pp. 307-310, 208-215.

Chamoso Lamas, M.: "Juan Bautista Celma y el arte del metal". En: Cuadernos de Estudios Gallegos, XII [T.], 38 [Fasc.], Santiago, (1957), pp. 307-310.

Chao Castro, D.: "Virgen de Belén". En: Camino de pa\%: Mane nobiscum Domine. Ourense, (2005), pp. 118-120.

Domínguez Fontela, J.: "Sepulcro de don Alvaro Pérez de Biedma en la catedral de Orense". En: Boletín de la Comisión Provincial de Monumentos de Orense, X [T.], 210 [Núm.], mayo-junio, (1935), pp. 64-65.

Dotación de la fiesta de San Clemente, y aniversario que fundó su señoría el señor Arcobispo Don Iuan de San Clemente Arçobispo de Santiago. (1600), Valladolid.

Duro Peña, E.: La música en la Catedral de Orense. Ourense. (1996).

Enríquez Morales, Ma. J.: "El Colegio de San Clemente de Pasantes y su fundador". En: Compostela y el Colegio de San Clemente de Pasantes. Santiago, (2004), pp. 31-35, 35-39.

Fariña Busto, F.: "Notas arredor da Sección Arqueolóxica". En: Exposición Galega de 1909. Conmemoración do $1^{\circ}$ Centenario. Exposición Regional Gallega. Santiago, 1909. Santiago, (2010), pp. 195-206.

Fernández Alonso, B.: El pontificado gallego. Su origen y vicisitudes, seguido de una crónica de los obispos de Orense. Orense. (1897).

Fernández Alonso, B.: "El coro de la catedral de Orense". En: Boletín de la Comisión Provincial de Monumentos... de Orense, IV [T.], 90 [Núm.], Orense, mayo-junio, (1913), pp. 297-306.

Fernández Sánchez, J.M./Freire Barreiro, F.: Guía de Santiago y sus alrededores. Santiago. (1885).

Flórez, E.: España Sagrada. XVII [T.], La iglesia de Orense. $3^{a}$ edic. Guadarrama. (2005). 
Folgar de la Calle, $M^{a}$. del C.: Simón Rodríguez: A Coruña. (1989)

Galicia Diplomática,: II [T.], 46 [Núm.], (1884), pp. 341-344.

Galicia Diplomática,: II [T.], 47 [Núm.], (1884), pp. 345-346.

Gallego de Miguel, A.: El arte del bierro en Galicia. Madrid. (1963).

García Iglesias, J. M.: La pintura manierista en Galicia. La Coruña. (1986).

García Iglesias, J. M.: Pinturas murais de Galicia. Santiago. (1989).

García Iglesias, J. M.: "Actividades artísticas aplicadas a los espacios construidos". En: El Reino de Galicia en la monarquia de Felipe II. Xunta de Galicia, Dirección Xeral de Patrimonio Cultural, (1998), pp. 533-534.

González Dávila, G.: Teatro eclesiástico de las iglesias metropolitanas...., I [T.]. Madrid. (1645).

González García, M. A.: "La catedral del siglo XVI”. En: La catedral de Orense. León, (1993), pp. 96-100, 110-111.

González García-Paz, S.: O Colexio de San Clemente de Pasantes de Compostela. Santiago. (1993).

Goy Diz, A.: "Colexios da Universidade". En: Vila Jato, M².D. (coord) (1996): O Patrimonio Histórico da Universidade de Santiago de Compostela. Estudios. Santiago, (1996), pp. 38-43, 38 y 42.

Goy Diz, A.: "El mecenazgo artístico de los Arzobispos Blanco y Sanclemente". En: El Reino de Galicia en la monarquía de Felipe II. Xunta de Galicia, Dirección Xeral de Patrimonio Cultural, (1998), pp. 590-592, 592-593, 602.

Guerra Campos, J.: Roma y el sepulcro de Santiago. La bula "Deus Omnipotens" (1884). Santiago. (1985).

Hoyo, J. del.: Memorias del arzobispado de Santiago. Transcripción del manuscrito original del año 1607. Edic. de Rodríguez González, A./Varela Jácome, B., Santiago, (s.a.). (1607).

Información e imágenes de la iglesia de san Pedro. En: cordobapedia.wikanda.es y wikipedia.org. [11-01-2016].

López Ferreiro, A.: Altar y cripta del Apóstol Santiago, reseña histórica desde su origen hasta nuestros días. Compostela. (1891).

López Ferreiro, A.: Historia de la Santa A. M. Iglesia de Santiago. VII [T.]. Santiago. (1904).

López Ferreiro, A.: Historia de la Santa A. M. Iglesia de Santiago. VIII [T.]. Santiago. (1906a).

López Ferreiro, A.: Historia de la Santa A. M. Iglesia de Santiago. VIII [T.]. Apéndice nº. LVI. Santiago. (1906b).

López Ferreiro, A.: Historia de la Santa A. M. Iglesia de Santiago. VIII [T.]. Apéndice nº LV. Testamento y codicilo del Arzobispo Don Juan de San Clemente. Santiago. (1906c).

Moralejo Álvarez, S.: Escultura gótica en Galicia (1200-1350). Resumen de tesis doctoral. Santiago. (1975).

Muñoz de la Cueba, Fr. J.: Noticias históricas de la Santa Iglesia Cathedral de Orense. Madrid. (1727).

Murguía, M.: El arte en Santiago durante el siglo XVIII y noticia de los artistas que florecieron en dicha ciudad y centuria. Madrid. (1884)

Navascués Palacio, P.: Teoría del coro en las catedrales españolas. Madrid. (1998).

Ortega Romero, M". del S. D.: "Las murallas de Compostela en los siglos XVI y XVII". En: Villares Paz, R. (coord.) (1988): La ciudady el mundo urbano en la bistoria de Galicia. Santiago, (1988), pp. 225-239.

Otero Túñez, R./Yzquierdo Perrín, R.: El coro del maestro Mateo. A Coruña. (1990).

Pardo Villar, Fr. A.: "El convento de santo Domingo de Betanzos". En: Boletín de la Real Academia Gallega. Año XXV, 227 [Núm.], La Coruña, 1 de septiembre. Año XXVI, 229, 230, 231, 232 y 233 [Núm.], La Coruña, 1 de enero, 1 de febrero, 1 de abril, 1 de junio y 1 de agosto, (1930), pp. 16-21, 40-45, 59-63, 83-87 y 112-120, respectivamente.

Pazos, M. R.: El episcopado gallego a la luz de los documentos romanos. I. [T.], Arzobispos de Santiago (1550-1850). Madrid. (1946a).

Pazos, M. R.: El episcopado gallego a la luz de los documentos romanos. II. [T.], Obispos de Tuy y Orense (1540-1855 y 1542-1851). Madrid. (1946b).

Pérez Costanti, P.: Notas viejas galicianas. I. [T.].Vigo. (1925)

Pérez Costanti, P.: Diccionario de artistas que florecieron en Galicia durante los siglos XVI y XVII. Santiago. (1930) 
Real Cédula de S. M.... en que se aprueban los Estatutos de la Real Sociedad Económica de Amigos del País de Santiago. (1787), Santiago.

Ríos Miramontes, Ma . T.: Aportaciones al barroco gallego. Un gran mecenazgo. Santiago. (1986).

Rivera Vázquez, E.: Galicia y los jesuitas. Sus colegios y enseñanza en los siglos XVI al XVIII. A Coruña. (1989).

Rodríguez González, A.: "Las murallas de Santiago en el siglo XVI". En: Cuadernos de Estudios Gallegos. XXIV [T.], 72-73-74 [Fasc.], Santiago, (1969), pp. 395-412.

Rodríguez Seoane, L.: "Discurso pronunciado en la solemne inauguración del Museo Arqueológico Central de Galicia”. En: Galicia Diplomática. Suplemento al 46 [Núm.], Santiago, 19 de julio. (1884).

Rodríguez Solís, E.: Glorias de España. María Pita (defensa de la Coruña en 1589). Madrid. (1898).

Rosende Valdés, A./Suárez Otero, J.: El coro lígneo de la catedral de Santiago de Compostela. Memoria bistórica, recuperación y restauración. A Coruña. (2004).

Saavedra Vázquez, Ma . C.: "El corsarismo inglés en Galicia: los ataques a Vigo y A Coruña y la militarización del reino". En: El Reino de Galicia en la monarquia de Felipe II. Xunta de Galicia, Dirección Xeral de Patrimonio Cultural, (1998), pp. 115 y ss.

Sacrosancti et Oecumenici Concilii Tridentini,... canones et decreta. (1762), Madrid.

Sánchez Arteaga, M.: Apuntes histórico-artísticos de la catedral de Orense. Orense. (1916).

Sanz del Castillo, P.: Vida del Excmo. Sr. D. Juan de San Clemente y Torquemada.... Santiago. (1769).

Vázquez Martínez, A. "Los jesuitas y la enseñanza de Gramática en Santiago (Siglo XVI)". En: Cuadernos de Estudios Gallegos. XXVI [T.], 79 [Fasc.], Santiago, (1971), pp. 178-186.

Vila Jato, $\mathrm{M}^{a}$. D.: Arte Galega Sánchez Cantón. Escultura manierista. Santiago. (1983).

Vila Jato, Ma.D.: A arte de Compostela. O Renacemento. O Castro. Sada. A Coruña. (1993a).

Vila Jato, M‥D.: Galicia. XII [T.] Galicia en la época del Renacimiento. A Coruña, (1993b), pp. 125-127.

Vila Jato, Mª.D. /García Iglesias, J.M.: Galicia. Arte. XII [T.] Galicia en la época del Renacimiento. A Coruña, (1993c), pp. 128-129.

Villa-amil y Castro, J.: Ensayo de un catálogo sistemático y crítico de algunos libros, folletos y papeles... que tratan en particular de Galicia. Madrid. (1875).

Yzquierdo Peiró, R.: Las colecciones de arte de la catedral de Santiago. Estudio museológico. Tesis doctoral. Universidad de Santiago. (2015), En: http://hdl.handle.net/10347/13784 [11 01-2016].

Yzquierdo Perrín, R.: "Dos capillas compostelanas dedicadas a la Virgen de las Angustias". En: III Semana Mariana en Compostela, Santiago, (1997), pp. 62-72.

Yzquierdo Perrín, R.: Reconstrucción del coro pétreo del Maestro Mateo. A Coruña. (1999).

Yzquierdo Perrín, R.: "Los palacios arzobispales de Santiago en la Historia y el Arte". En: Instrumentos de corda medievais. Lugo, (2000), pp. 20-89.

Yzquierdo Perrín, R.: "Intervenciones en la catedral de Santiago de Compostela desde 1875: de López. Ferreiro a Chamoso Lamas". En: A Coruña no obxectivo de Manuel Chamoso Lamas. As nosas raíces. A Coruña, (2004), pp. 22-26, 34-37.

Yzquierdo Perrín, R.: "El mecenazgo del arzobispo compostelano Don Lope de Mendoza en Santiago y Padrón”. En: Abrente, 38-39 [Núm.], A Coruña, (2006-2007), pp. 117-172.

Yzquierdo Perrín, R.: "Noticias sobre las sillerías de coro medievales en las catedrales de Galicia". En: Fernández Gracia, R. (coord.) (2011): Pvlchrum. Scripta varia in honorem $M^{a}$. Concepción García Gaínza. Pamplona, (2011), pp. 831-832. 